أثر استخدام أربعة أساليب تدريس في تتمية بعض مهار ات كرة السلة

لطالبات الأول المتوسط

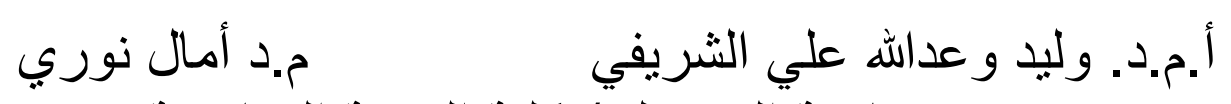
جامعة الموصل / كلية التربية الرياضية

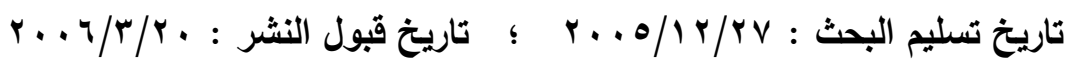

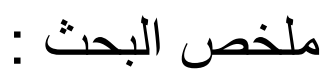

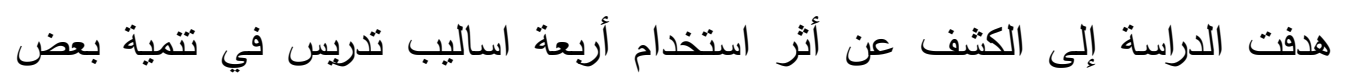

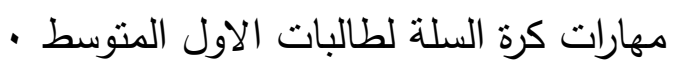

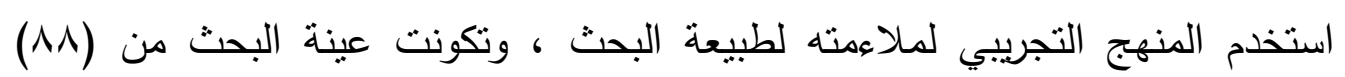

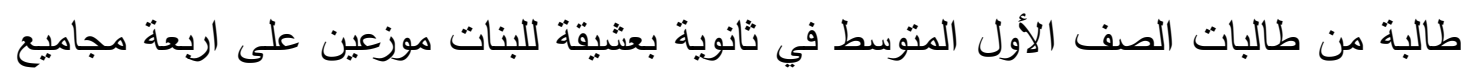

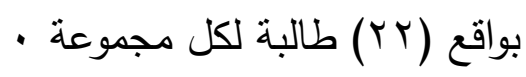

وتم التكافؤ بينهم في متغيرات (العمر والطول والوزن) فضلا عن عند عدد من عناصر

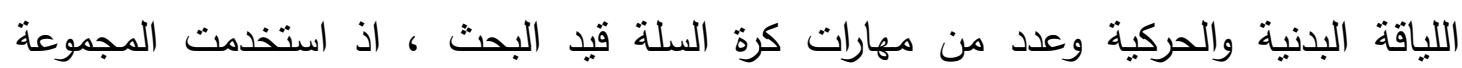
التجريبية الأولى أسلوب التضمين في التدريس ، بينما استخدمت المجموعة التجريبية الثانية

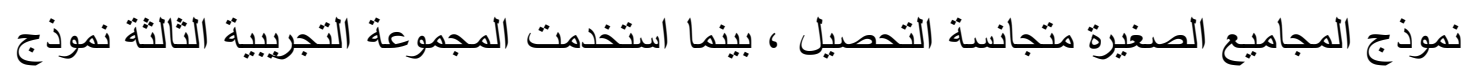
المجاميع الصغيرة غير المتجانسة التحصيل ، في حين استخدمت المجموعة التجريبية الرابعة

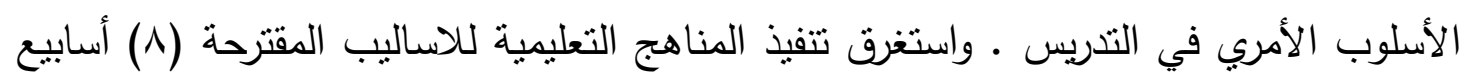

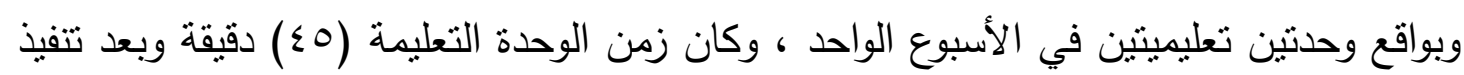
البرامج أجري الاختبار البعدي ، وبعدها تم جمع البيانات ومعالجتها احصائيا باستخدام الوسائل الئل

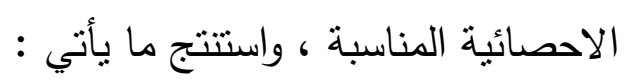

ا. حقق اسلوب التضمين ونموذجين من المجاميع الصغيرة (المتجانسة وغير المتجانسة) تتمية وانية

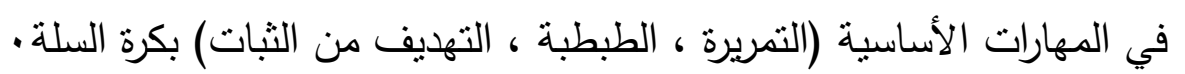
r. حقق الأسلوب الأمري تتمية في مهارة التمريرة الصدرية. r. تفوق نموذج المجاميع الصغيرة متجانسة التحصيل في تتمية مهارة التهديف عند مقارنتها بالاساليب الندريسية الأخرى. 


\section{The Effect of Using Four Teaching Styles in Developing some skills in Basketball For Female Pupils at Secondary First Year}

\section{Dr. Waleed W. A. Al-Shareffy Dr. Amal Nory Betres University of Mousl - College of Sport Education}

Abstract:

The research aims at revealing the effect of using four teaching styles in developing some skills in basketball at first year female pupils. The study is based on the experimental approach due to its suitability. The Society of the research were 88 first year female pupils at their intermediate stage in Ba'sheeq. They were divided into four groups each of which consisted of 22 pupils. Equivalence concerning the variables age, height and weight was achieved in addition to a number of elements of physical and some basic skills in basketball. The first experimental group used the inclusion style in teaching whereas the second experimental group used small homogenous groups. The third used the sample of small heterogeneous groups while the fourth experimental group used the command style. The execution of the educational program lasted 8 weeks with the average of two educational units per week. The time devoted for each educational unit was 45 minutes. The data were collected and tested statistically by using mean, standard deviation, simple correlation coefficient (Person), T-test for equal correlated samples, analysis variance in one direction and Duncan's L.S.R. The analysis showed the following findings:

1. The inclusion style and the two samples of small groups styles were found more effective in developing some basic skills like passing, dribbling and shooting in basketball.

2. the command style were found developing in skill pass.

3. The sample of small homogeneous groups compared with the other educational styles was found more effective in developing the shooting skill. 
ان اكثر الدجمعات تقدماً في مجالات الحياة هي تلك التي تعطي التربية التربية الرياضية

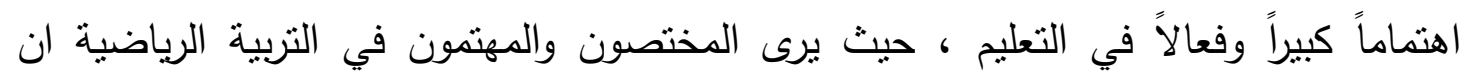

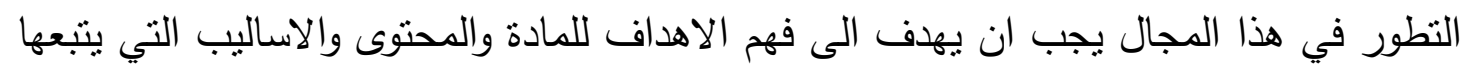
المربون في الوصول الى تحقيق الاهداف والمستوى ، والطرق التي يمكن الن النت التبع في تدريسها

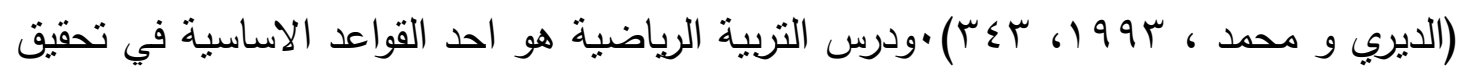

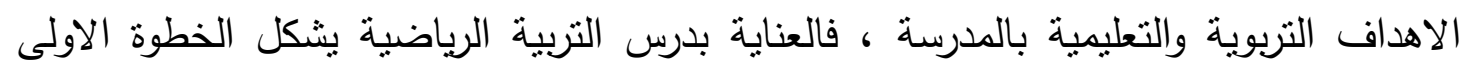

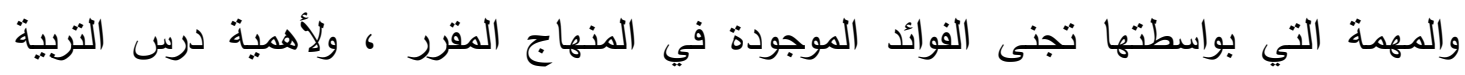

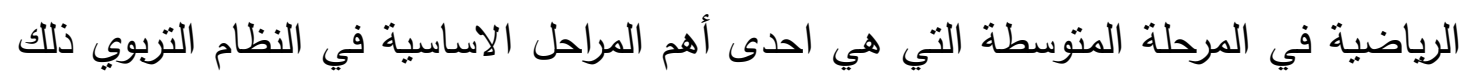

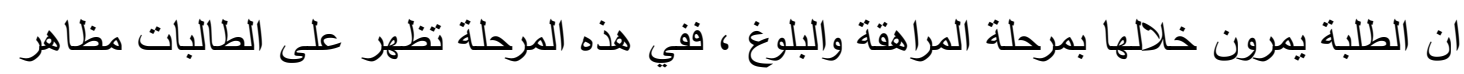

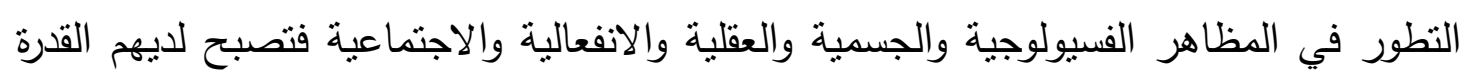

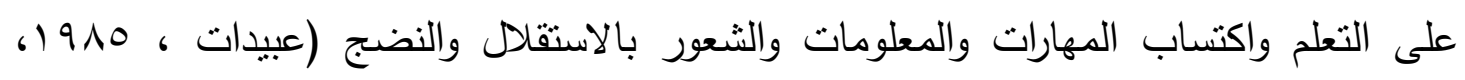

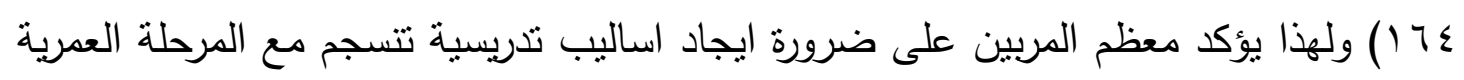

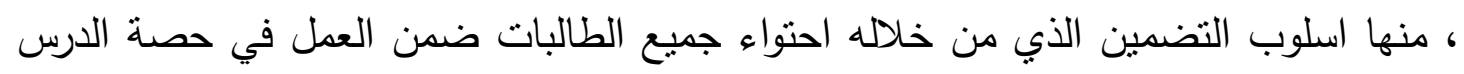

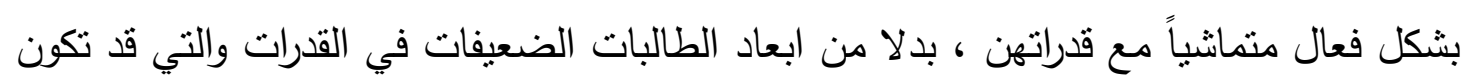

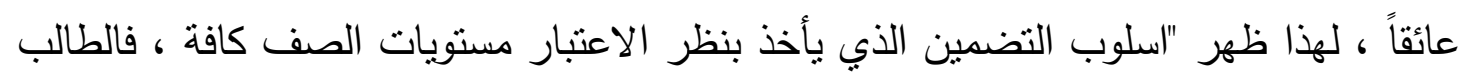

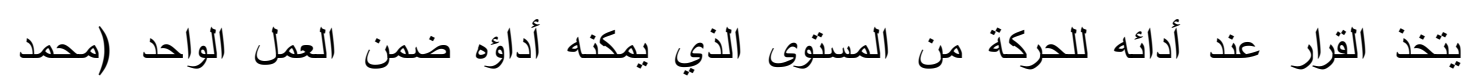

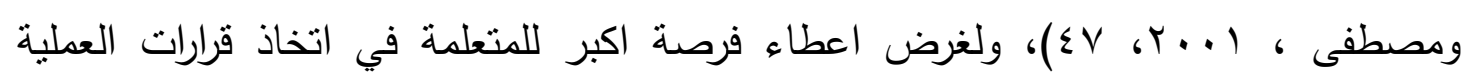

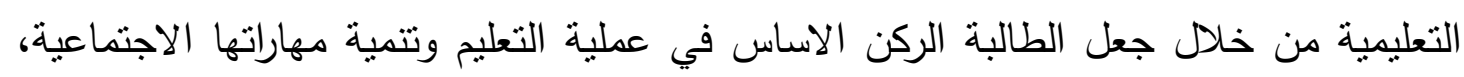

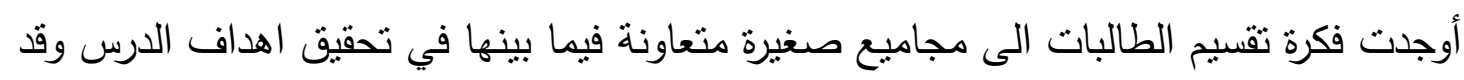

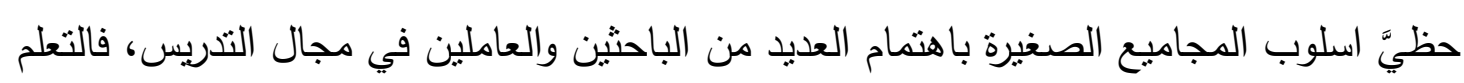

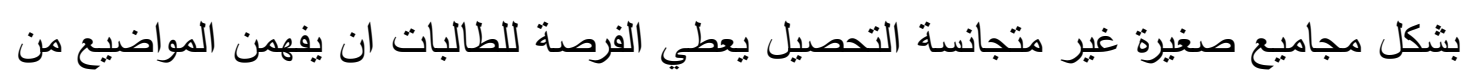

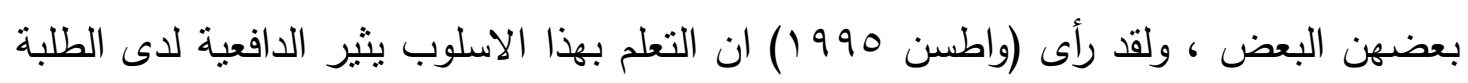

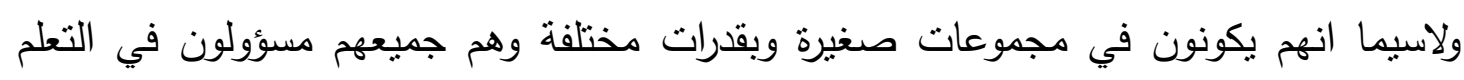

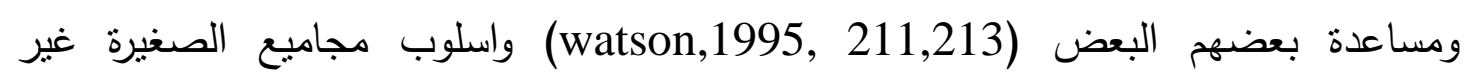

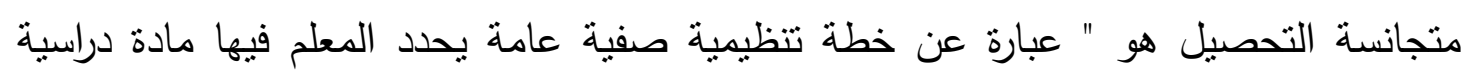

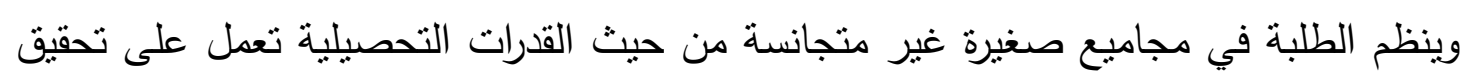

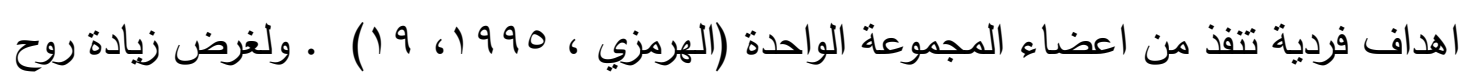

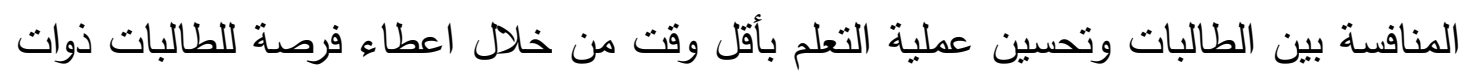


المستوى العالي بالعمل دون أي إعاقة من ذوات المستويات الاخرى واعطاء الاهتمام الكبير من

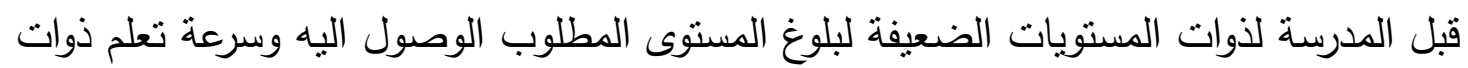
المستوى المتوسط في القدرات ، أوجد اسلوب تقسيم الطالبات الى مجاميع صغيرة متجانسة

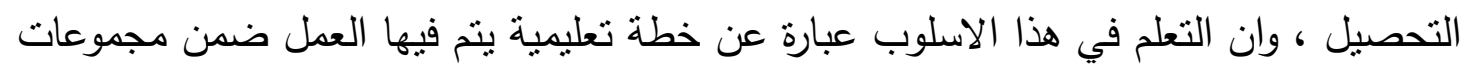

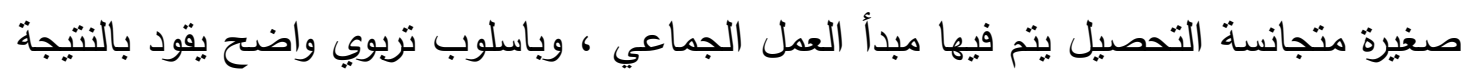
الى ترسيخ الصفات الاساسية للثخصية الاشتراكية لدى الطالب ويوطد العلاقة التربوية

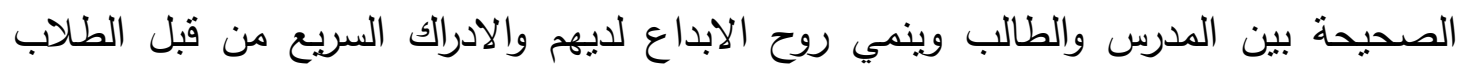

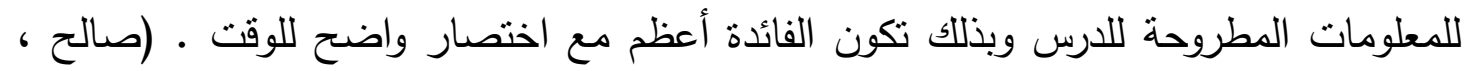

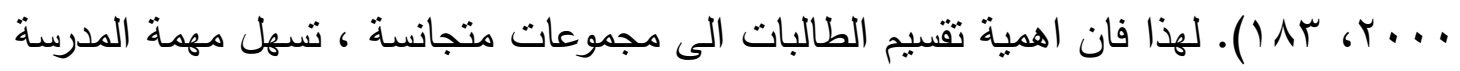

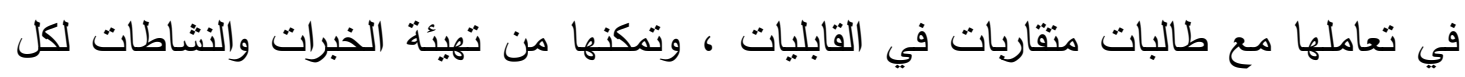
مجموعة ، وان وجود الطالبة في مجموعة صغيرة قريبة من مستواها تجعلها اكثر حماساً ونشاطاً

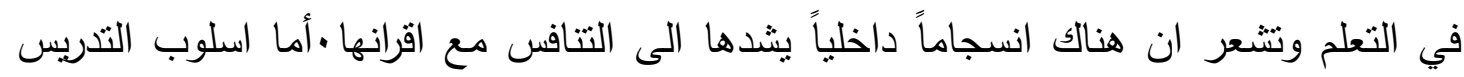

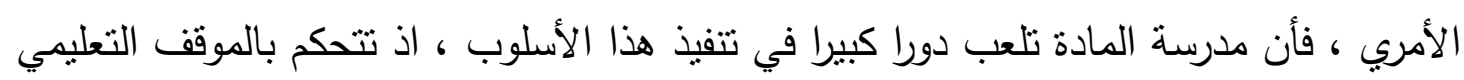

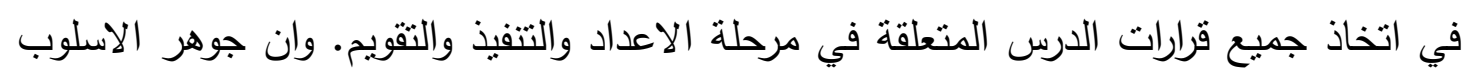

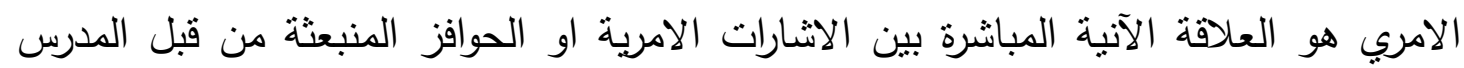

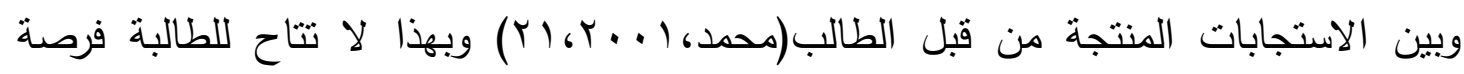
للابداع والتعاون او المشاركة في اتخاذ القرارات فقط، ولكن عليها الاستجابة الفورية لهذه القرارات

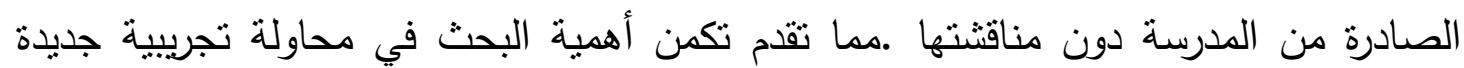

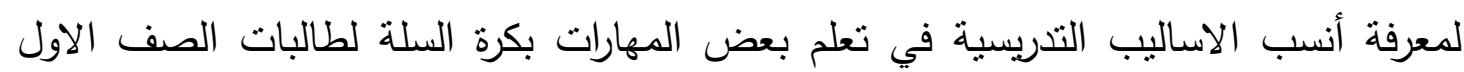

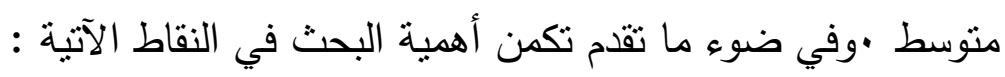

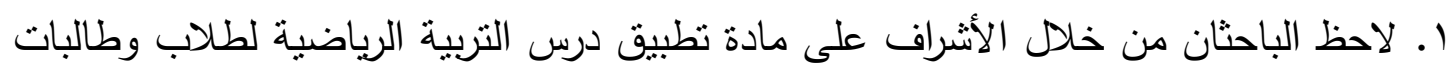

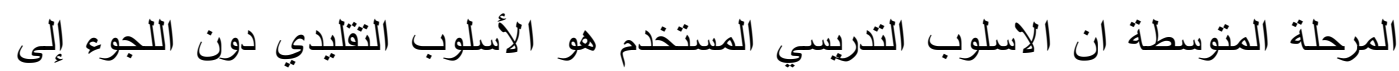

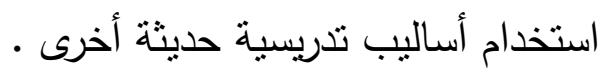
r. قلة الدراسات في البيئة العراقية والعربية على حد علم الباحثان بخصوص استخدام اسلوبي

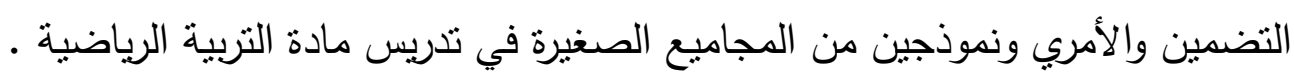

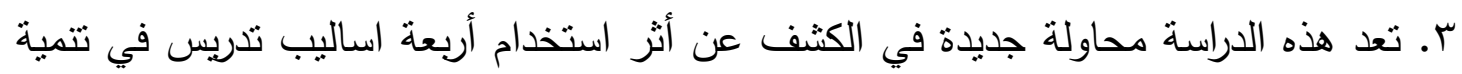

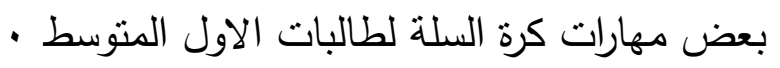


اصبحت الحاجة الى الارتقاء بمستوى تدريس مادة التزبية الرياضية في مدارسنا عموماً

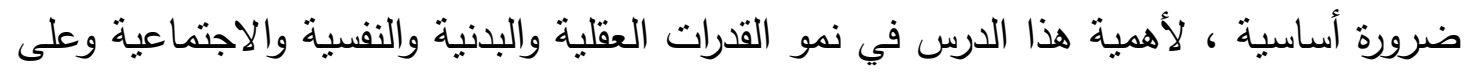
وجه الخصوص طالبات المرحلة المتوسطة لكون هذه المرحلة ذات اهمية باعتبارها مرحلة

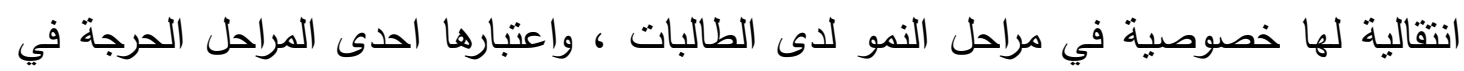

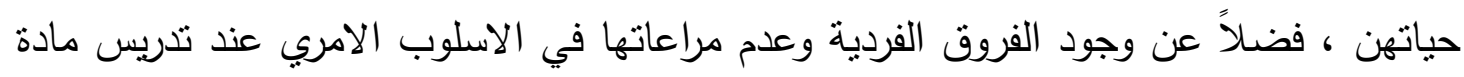
التربية الرياضية ، لهذا يتطلب ايجاد الكثير من الاساليب التدريسة الحديثة وتطبيقها بهدف تعزيز

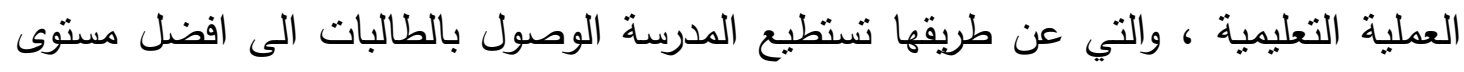

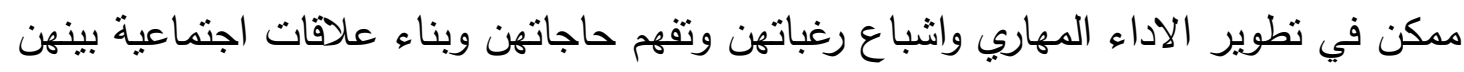

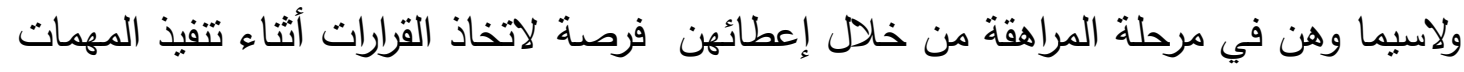

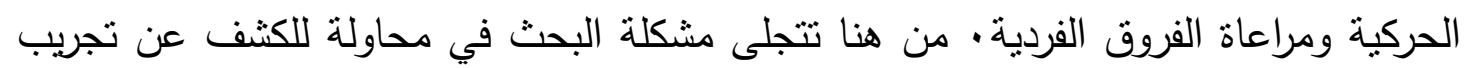

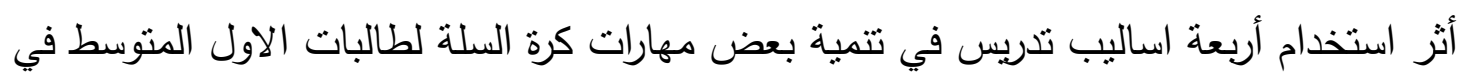
درس التربية الرياضية .

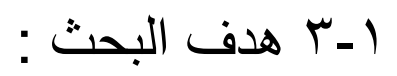

- الكثف عن أثز استخدام اسلوبي التضمين والأمري ونموذجين من المجاميع الصغيرة (المتجانسة وغير المتجانسة) في تتمية بعض مهارات كرة السلة .

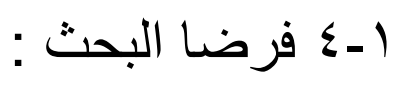

- وجود فروق ذات دلالة معنوية بين الاختبارين القبلي والبعدي لمجاميع البحث الاربع في تتمية

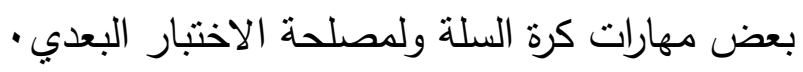

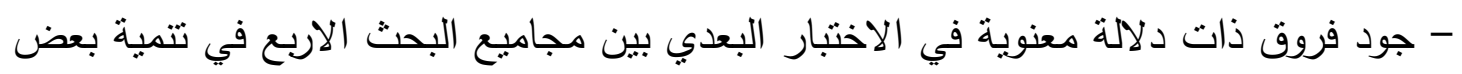
مهارات كرة السلة.

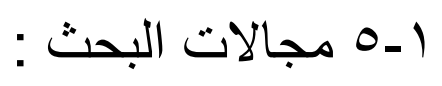

- المجال البشري : طالبات الصف الاول متوسط في ثانوية بعشيقة للبنات/محافظة نينوى/ العراق

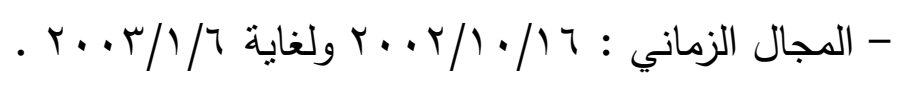

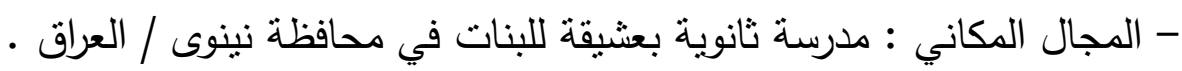


r - الاطار النظري والدر اسات السابقة : الإر

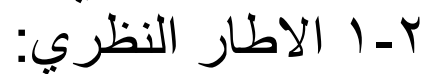

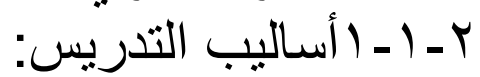

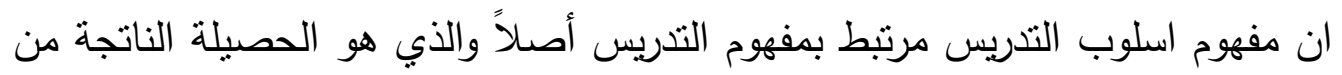

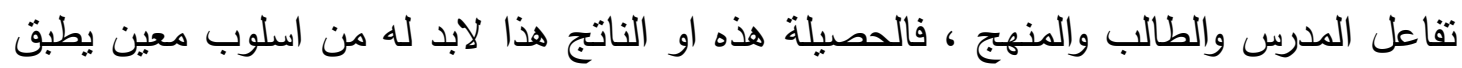

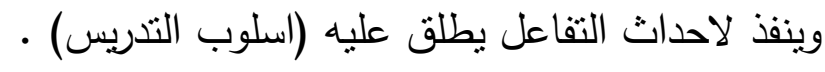

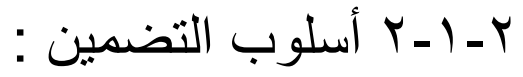

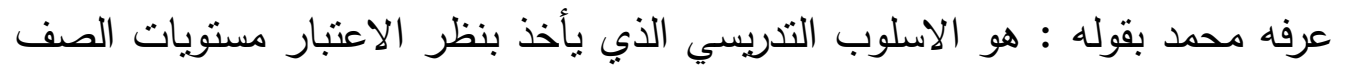

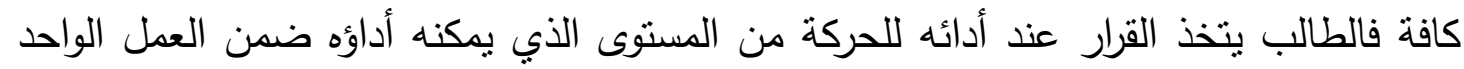

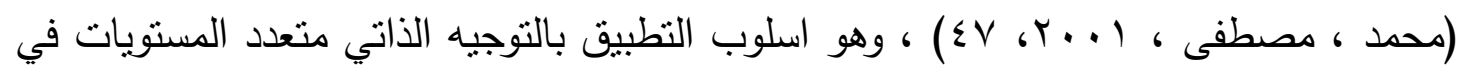

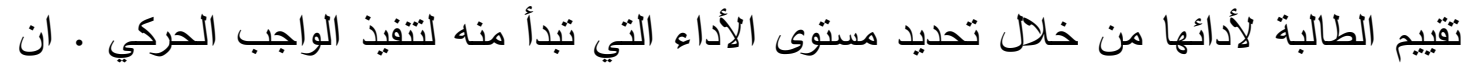
الفروق الفردية من المظاهر العامة في الصف والمدرسة ، وان مدرسة مادة التربية الرياضية عادة تواجه تلك الفروق بين الطالبات في القدرات البدنية والحركية والمهارية واختلاف اتجاهاتهن فئه فئه

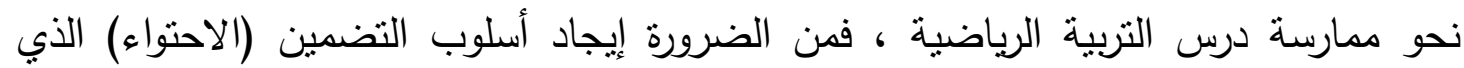

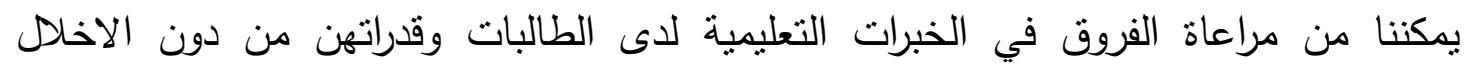

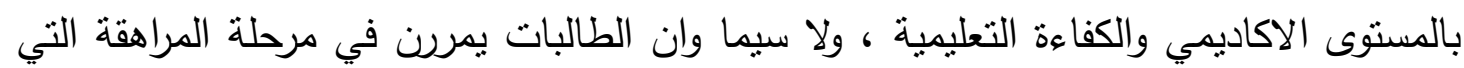

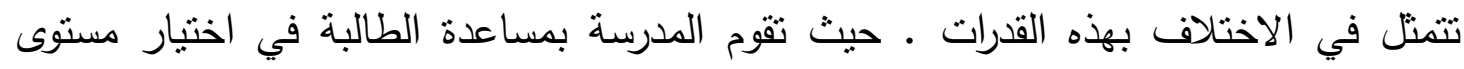

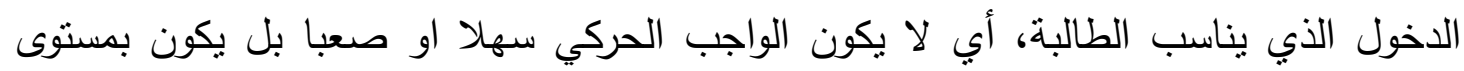
يمكن جميع الطالبات من الاشتراك في اداء الواجب الحركي المطلوب وكل حسب لوابت قدراتهن وتوفير فرص النتافس بينهن.

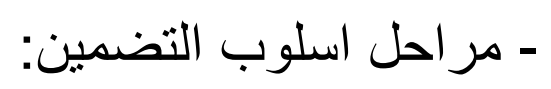
أولاً. مرحلة ما قبل الدرس (الاستعداد):يقوم المدرس باتخاذ جميع القرارات في هذه المرحلة، ومن اجل تقديم الاسلوب الى صف جديد ، يهيء الددرس تقديم (الفكرة) ويراجع مراحلها.

ثانياً. مرحلة الدرس (الأداء) : تهيئة الدرس عن طريق عرض الفكرة ، ويمكن ان يتم ذلك بواسطة الثرح ، او توجيه عدد من الاسئلة الى التلميذ تؤدي الى اكتثاف الفكرة المراد 
1. تحديد الهذف الاساسي للاسلوب - احتواء التلميذ في اداء الواجب بواسطة ايجاد مدى معين

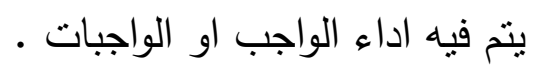

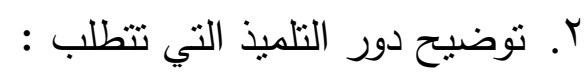

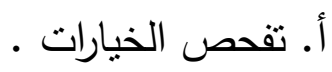

ب. اختيار المستوى الابتدائي للاداء بحيث لا يكون مستوى سهلا او صعبا .

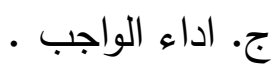

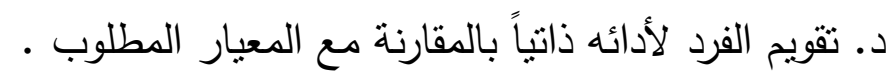

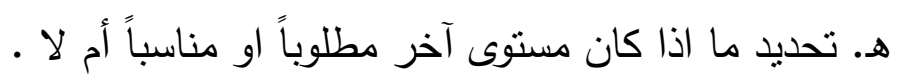

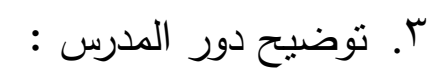

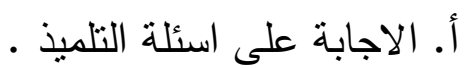

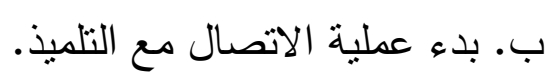

ع. عرض وتقديم موضوع الدرس ، ووصف (البرنامج الفردي) ـ أب تحدد العامل الذي يقرر

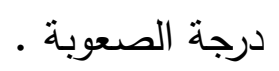

•. وضع الاجراءات التنظيمية والادارية ووضع القياسات او المقاييس الضرورية ثم بامكان تلاميذ الصف الانتشار والبدء بواجباتهم الفردية .

ثالثاً. مرحلة ما بعد الدرس (التقويم):

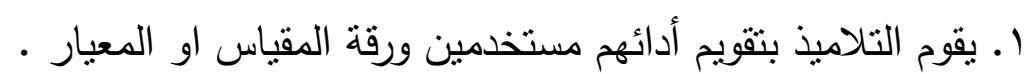

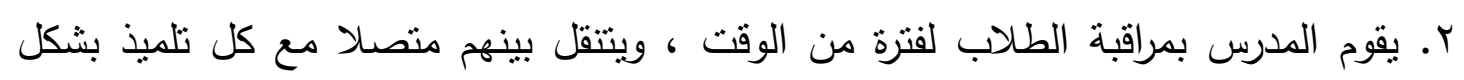
فردي واعطاء التغذية الراجعة حول مستوى مشاركة التلميذ وقيامه بدوره

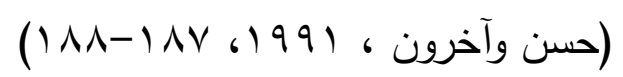

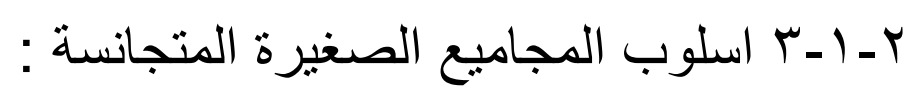

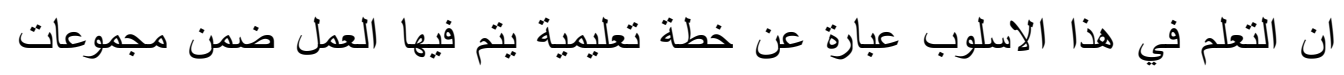

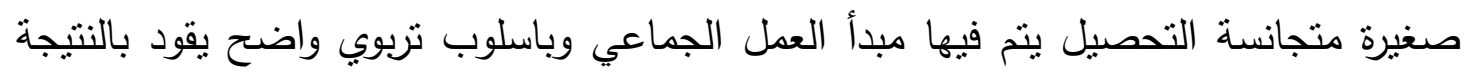
الى ترسيخ الصفات الاساسية للثخصية الاشتراكية لدى الطالب ويوطد العلاقة التربوية

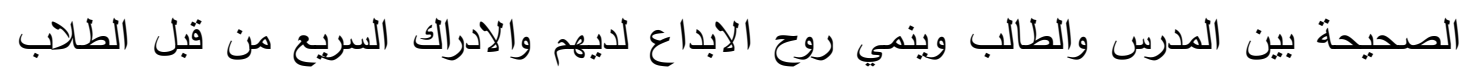

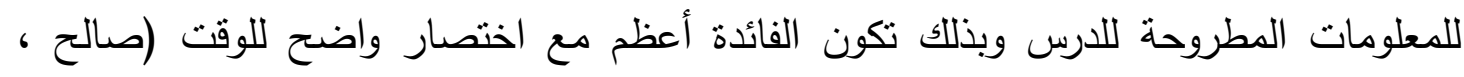

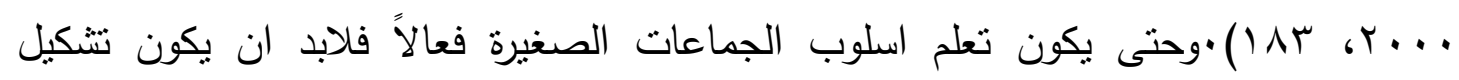

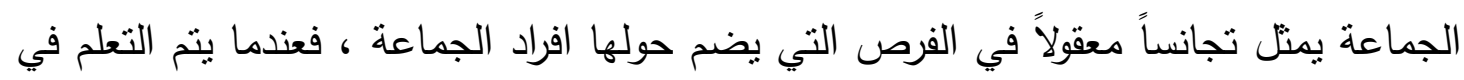
جماعات متجانسة يجب ان تتثكل كل مجموعة صغيرة من افراد متثابهين من ناحية احتياجات 
التعلم حتى يتيسر للمدرس معالجة الموقف ، فالتجانس لابد ان يكون في المجال البدني او الواري

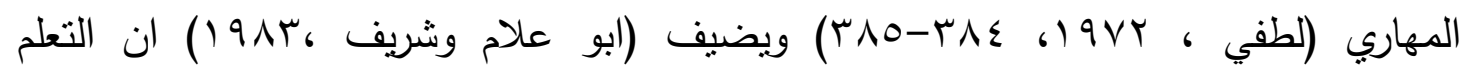

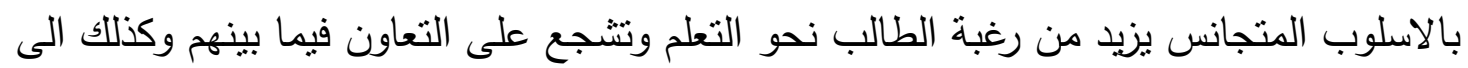

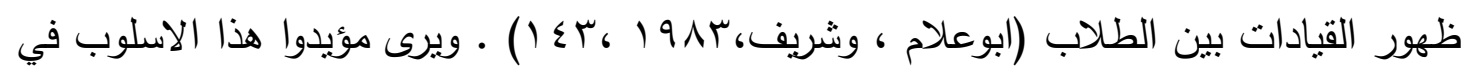

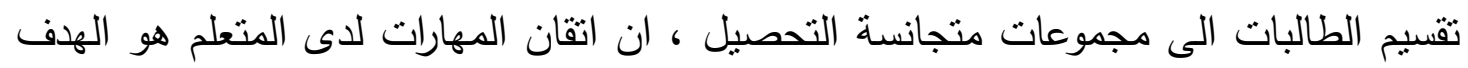

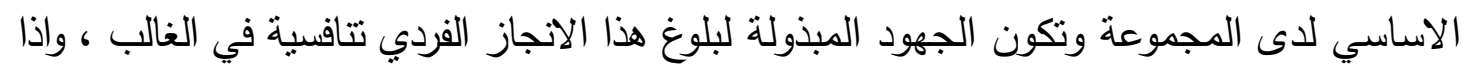

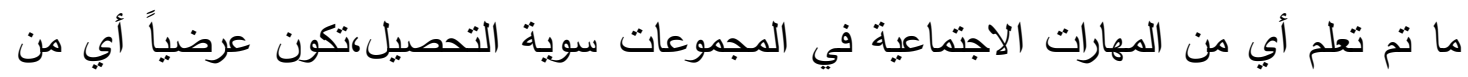

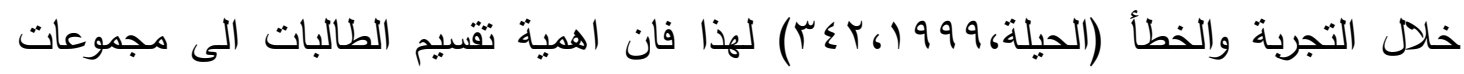

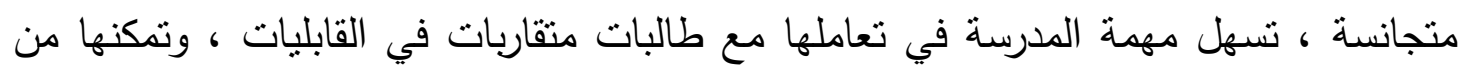

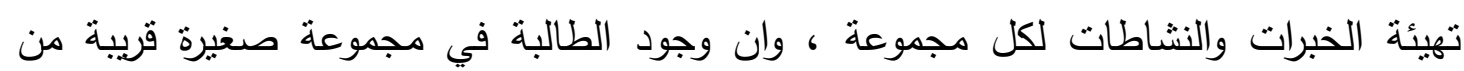

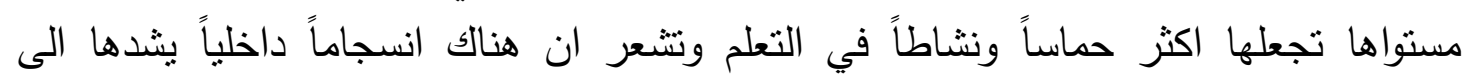

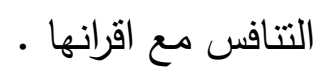

\section{Y - ا - ـ اسلوب المجاميع الصغيرة الغير متجانسة :}

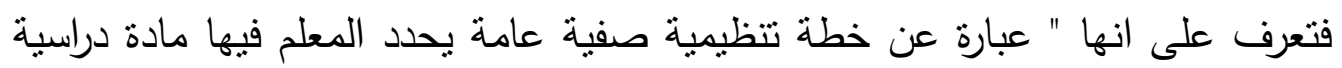

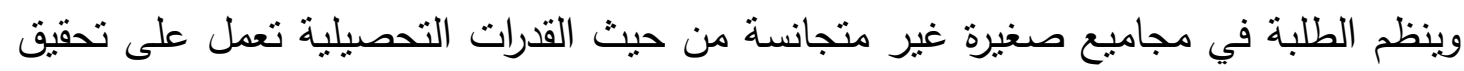

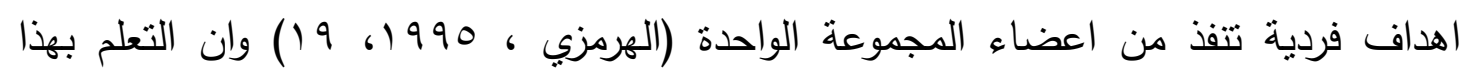

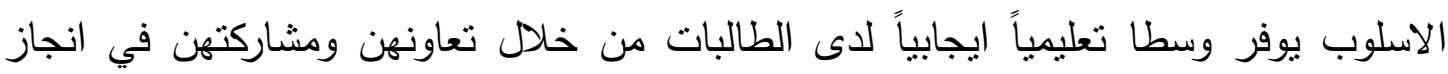

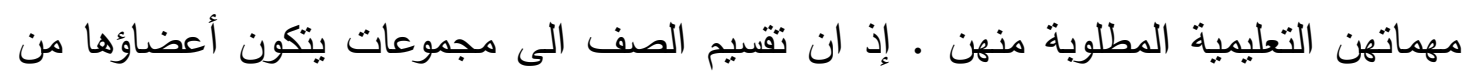

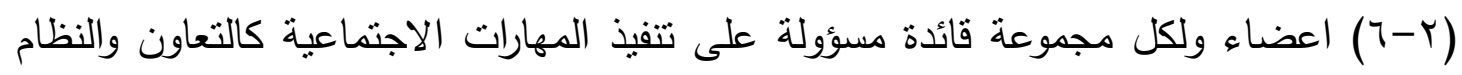

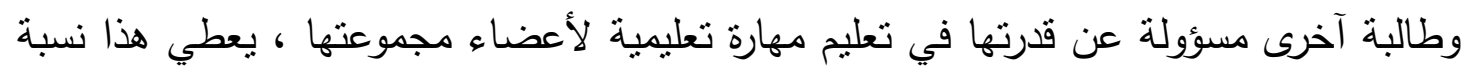

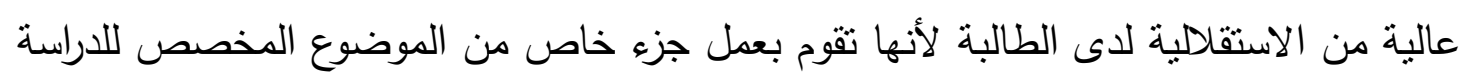

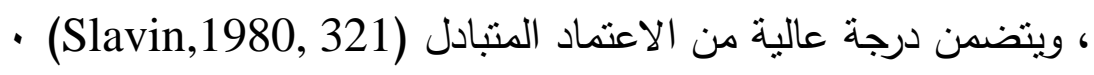
- دور المدرس في تعلم المجموعات الصغيرة : يتعدى دور المدرس تتظيم مواقف التعلم وذلك الإن من خلال

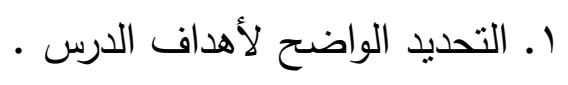

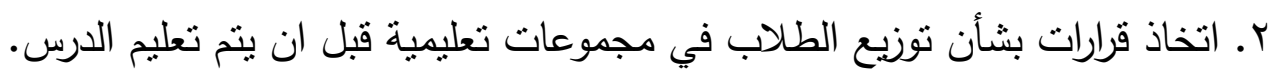

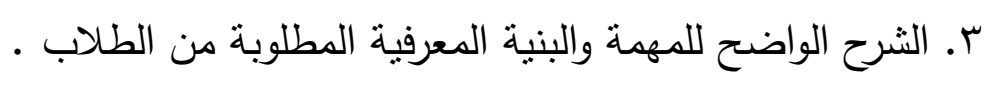

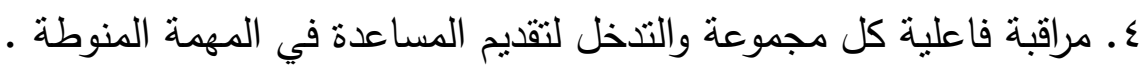

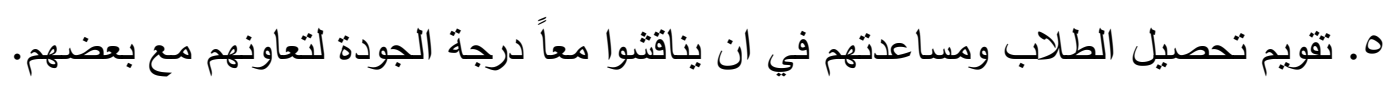

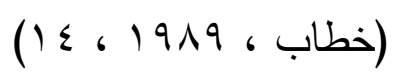




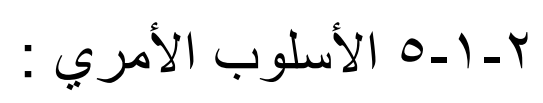

تلعب مدرسة المادة دورا كبيرا في تتفيذ الأسلوب الأمري فالدور الاساسي في هذا

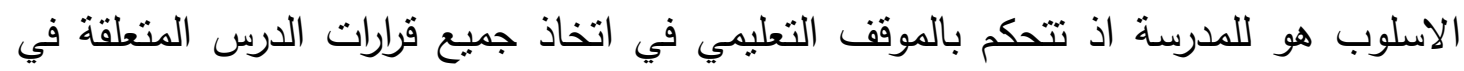

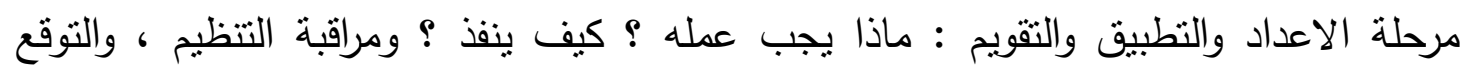

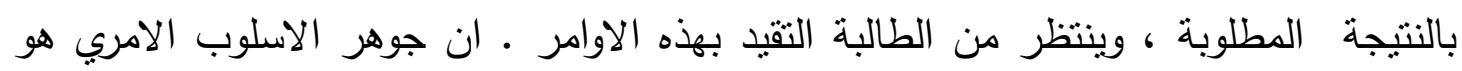

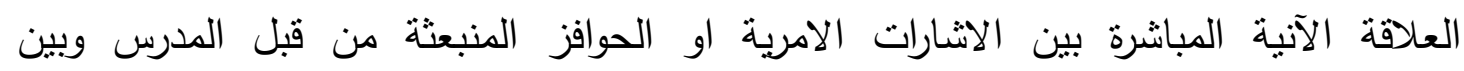

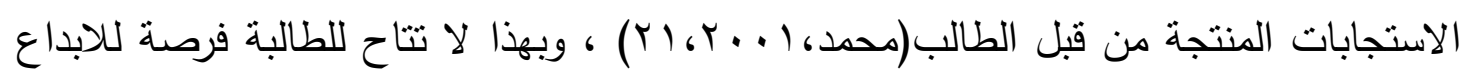

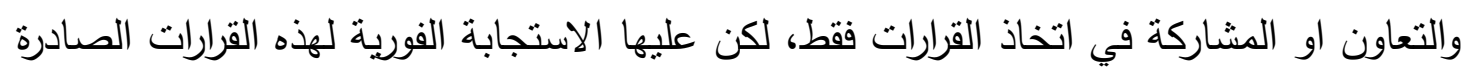

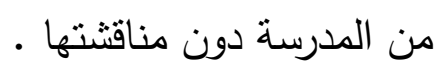

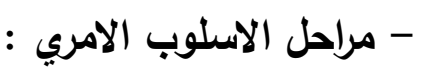
أولا. مرحلة ما قبل الدرس (الاستعداد): يقوم المدرس باتخاذ جميع القرارات في هذه المرحلة فهو

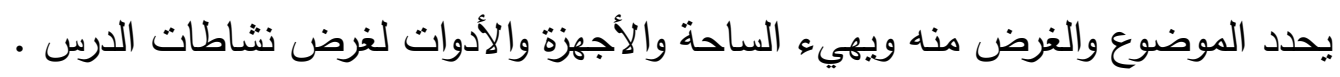
ثانيا. مرحلة الدرس (الأداء) : 1. الثرح : يقوم المدرس في بداية الدرس بشرح المهارة او المهارات لفظياً ثم يقدم نموذجاً لها

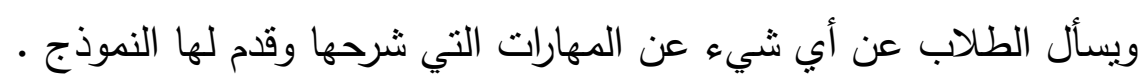

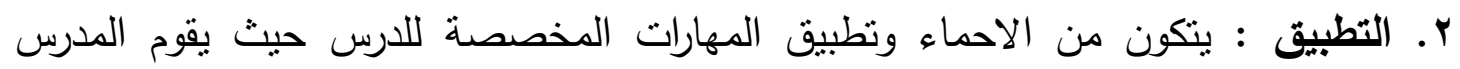

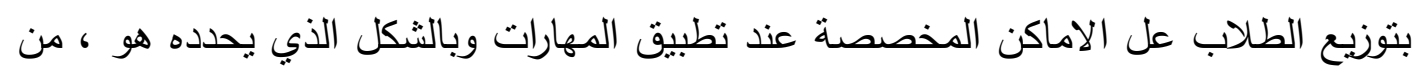

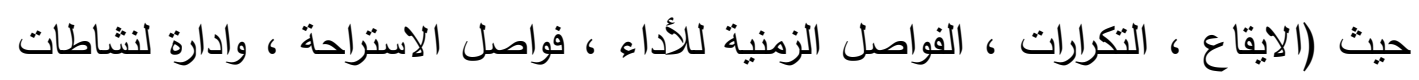

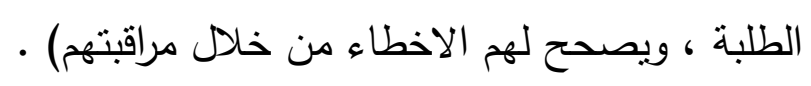
r. التقويم : تكون من قبل الددرس وعلى شكل فترتين الاولى أنثاء تطبيق الطلاب للمهارات.

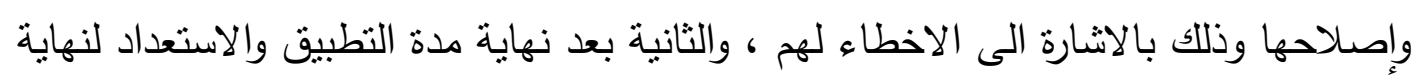
الدرس

ثالثا. مرحلة نهاية مراسيم الارس: المدرس يجمع الأدوات والتجهيزات ويوقف الطلبة استعدادا

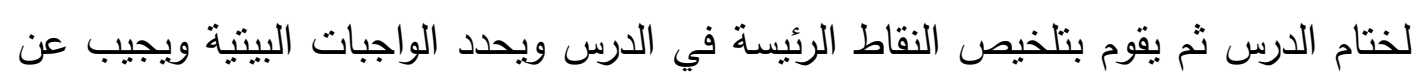

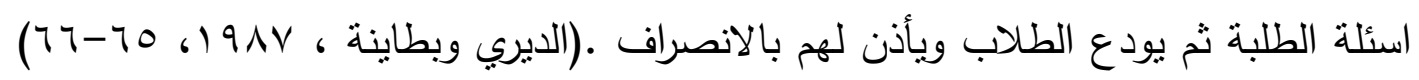

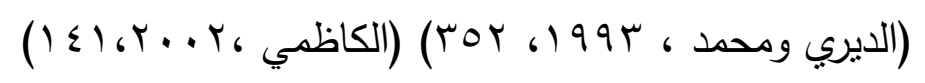




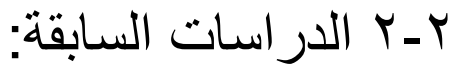

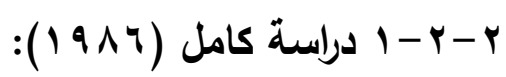

"تأثير ثلاثة أساليب للتدريس على مستوى الاداء الحركي"

هدفت الدراسة للتعرف على ددى تأثير ثلاثة اساليب تدريسية (الامري والتدريبي الائي

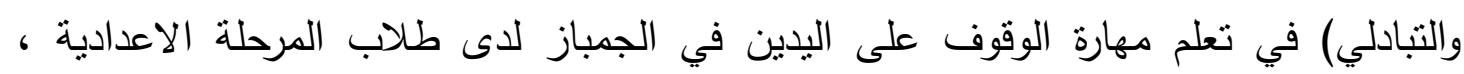

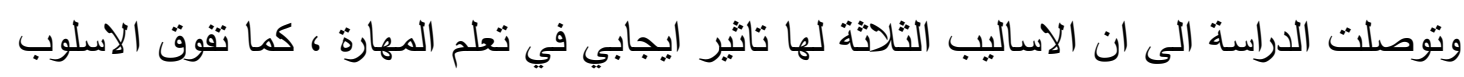
التبادلي على اسلوبي الامري والتدريبي في تعلم مهارة الوقوف على اليدين في الجمباز •.

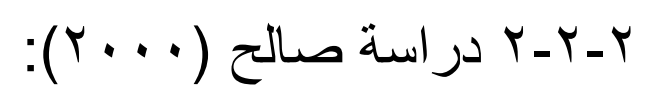

"تأثير أريعة أساليب للتدريس على أكتساب مهارات مختارة لكرة السلة " ل

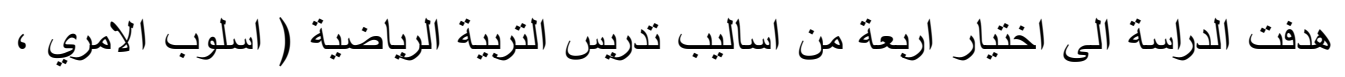

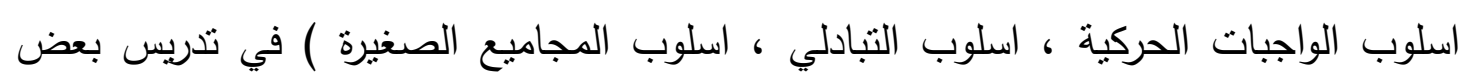

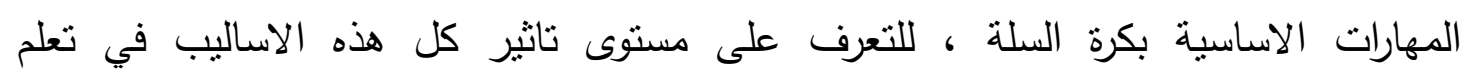

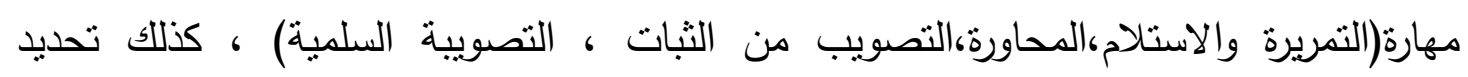

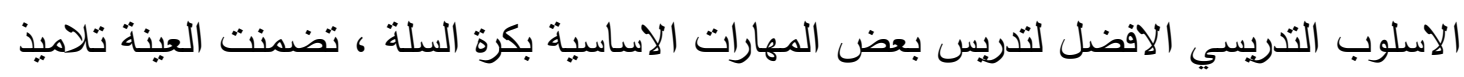

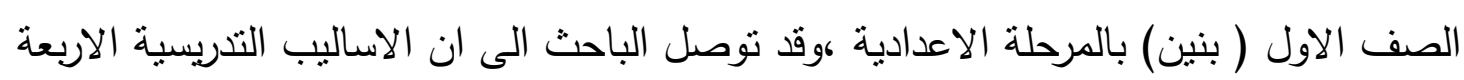
قبد البحث اثتتت صحتها بصفة عامة .

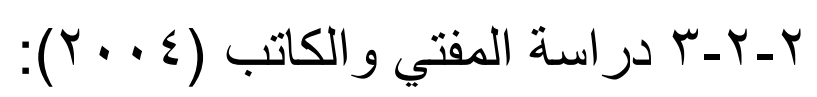

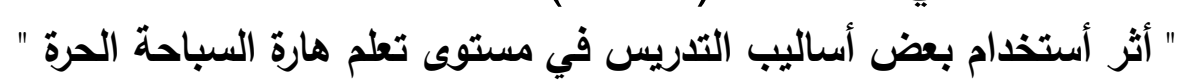

هدفت الدراسة للتعرف على بعض اساليب التدريس في تعلم مهارة السباحة الحرة ،

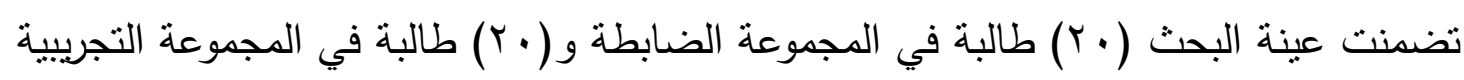

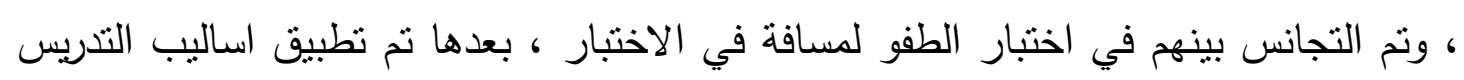

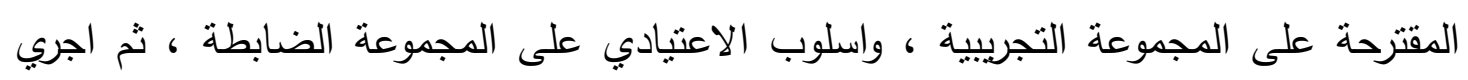

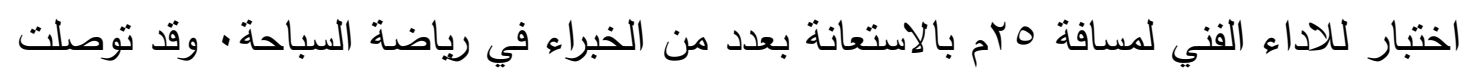

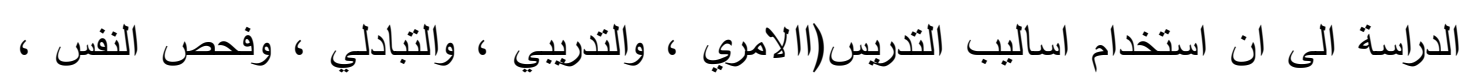
والتضمين) يؤثر ايجابا في مستوى تعلم السباحة الحرة للطالبات. 


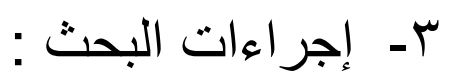

ץ-1 منهج البحث : : نم استخدام المنهج التجريبي لملاعهته لطبيعة مشكلة البحث،

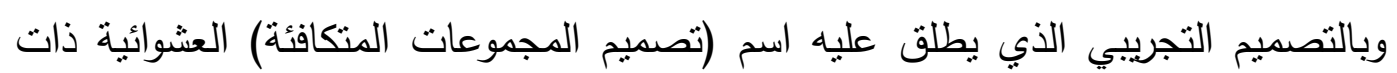

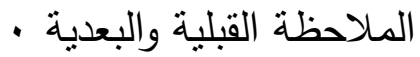

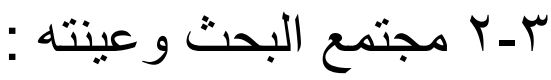

تكون مجتمع البحث من طالبات الصف الاول المتوسط في ثانوية بعشيقة للبنات والبالغ

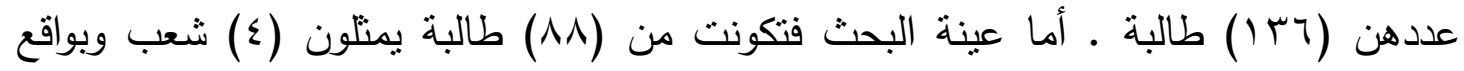
(Yr) طالبة لكل شعبة ، بعد استبعاد (I^) طالبة ، وبذللك اصبحت عينة البحث تمنل

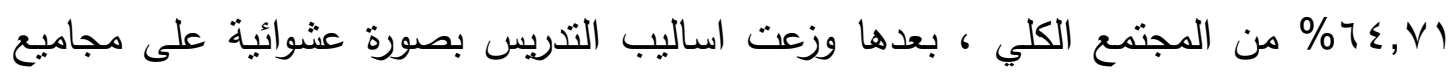

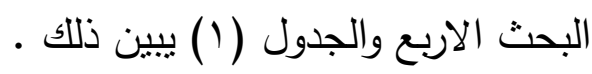

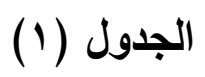

يبين عدد افراد عينة البحث والاسلوب المتبع لكل عينة

\begin{tabular}{|c|c|c|c|c|c|}
\hline الاسلوب & المجموعة & عينة & المستبعد & الكلي & الاراسية \\
\hline التضمين & التجريبية الاولى & rr & ir & $r \varepsilon$ & 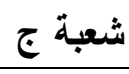 \\
\hline المجاميع الصغيرة (المتجانسة التحصيل) & التجريبية الثانية & rY & ir & ro & 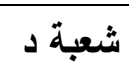 \\
\hline (غير المتجانسة التحصيل) & التجريبية الثالثة & rr & ir & $r \varepsilon$ & 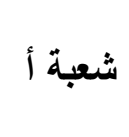 \\
\hline \multirow[t]{2}{*}{ ال الأمري } & التجريبية الرابعة & rr & 11 & r & 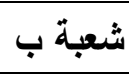 \\
\hline & & $\wedge \wedge$ & $\leqslant \wedge$ & 4T4 & المجموع \\
\hline
\end{tabular}

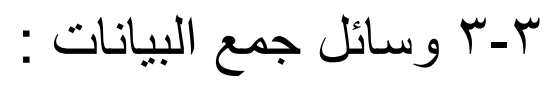

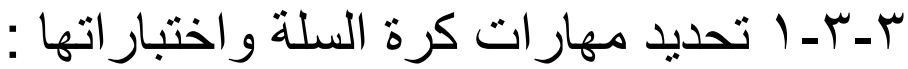

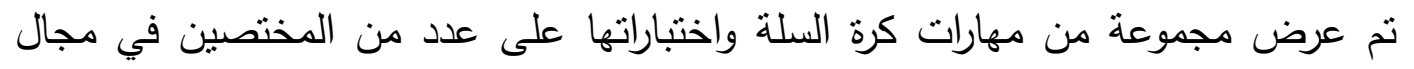
لعبة كرة السلة (الملحق ())، وتم استخلاص مجموعة من بعض مهار مهارات كرة السلة وإختباراتها،

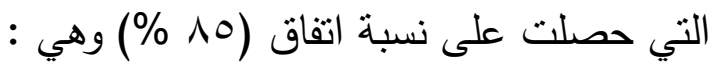

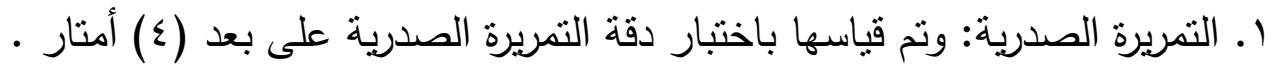

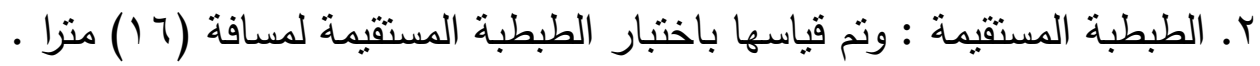

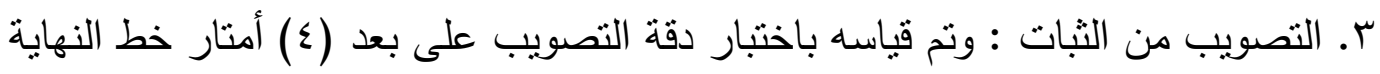


r-Y_r الأسس العلمية للأختبار ات المعدة لقياس بعض مهار ات كرة السلة - صدق الاختبار : عرض الاستبيان على عدد من المختصين في هذا المجال (الملحق () ، وقد

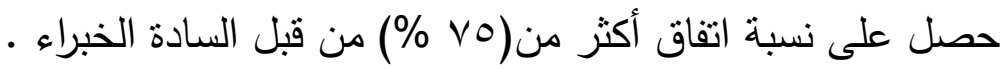

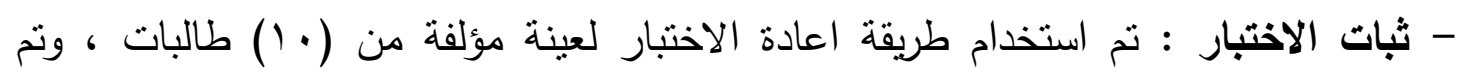

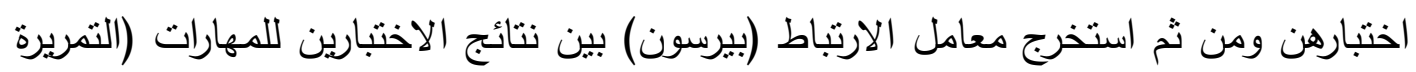

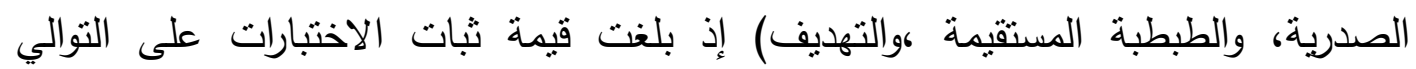

$$
\left(\cdot, \wedge \varepsilon \cdot \cdot, \wedge \vee_{6} \cdot, \wedge \wedge\right)
$$

r-r-r تحديد عناصر اللياقة البدنية المؤثرة في تتمية بعض مهارات كرة السلة: - الب

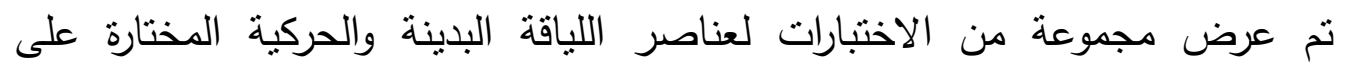

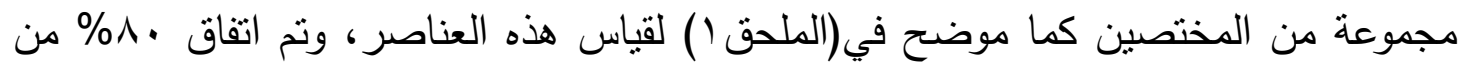

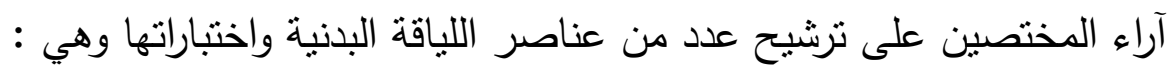

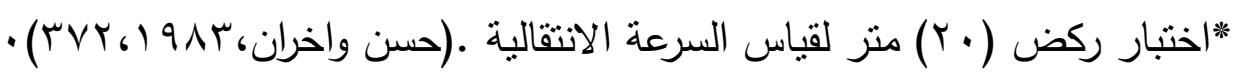

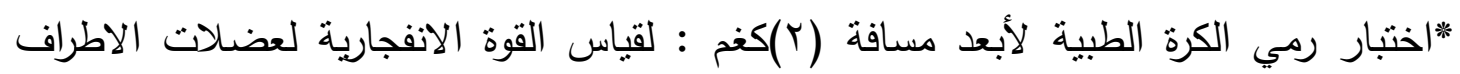

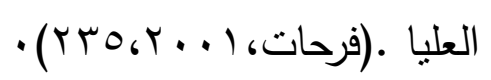
*اختبار الوثب الطويل من الثبات لأبعد مسافة : لقياس القوة الانفجارية لعضلات الاطراف

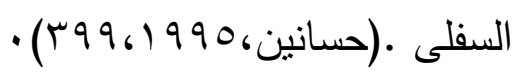

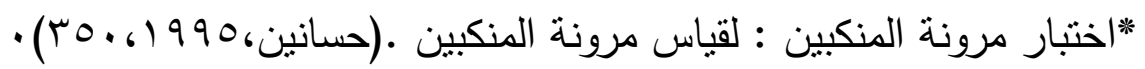

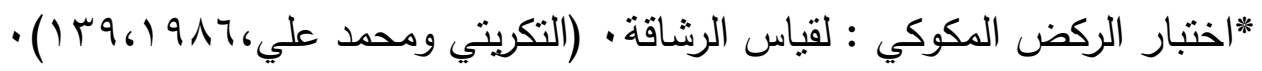

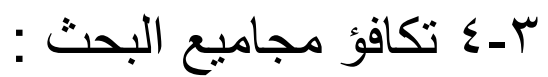
(r) (الجدول

تحليل التباين لمتغيرات العمر والطول والوزن لمجموعات البحث الأريع

\begin{tabular}{|c|c|c|c|c|c|c|}
\hline قالمتسبة ف & المربعات & الرية & المربعات & مصدر القياس & والمدتخدمة القياس & المتغيرات \\
\hline \multirow{3}{*}{ • } & $r 1,1$ & $r$ & $94, r$ & بين المجموعات & \multirow{3}{*}{ لأقرب شهر } & \multirow{3}{*}{ العمر } \\
\hline & $\{\wedge, 1$ & $\Lambda \varepsilon$ & $\varepsilon \cdot r q, r$ & داخل المجموعات & & \\
\hline & & $\Lambda V$ & $\varepsilon 1 \times 9, \varepsilon$ & المجموع & & \\
\hline \multirow{3}{*}{$1, \times 9$} & $04, \xi$ & $r$ & 179,1 & بين المجموعات & \multirow{3}{*}{ سنتيمتر } & \multirow{3}{*}{ الطول } \\
\hline & ૫ & $\Lambda \varepsilon$ & Mrro,0 & داخل المجموعات & & \\
\hline & & $\Lambda V$ & $r \wedge r \leq, Y$ & المجموع & & \\
\hline \multirow[t]{2}{*}{$\cdot, 1 \leqslant$} & 9,0 & $r$ & $\uparrow \Lambda, \uparrow$ & بين المجموعات & \multirow[t]{2}{*}{ كيلوغرام } & \multirow[t]{2}{*}{ الوزن } \\
\hline & $74,$. & $\Lambda \varepsilon$ & $00 \leqslant 1, V$ & داخل المجموعات & & \\
\hline
\end{tabular}




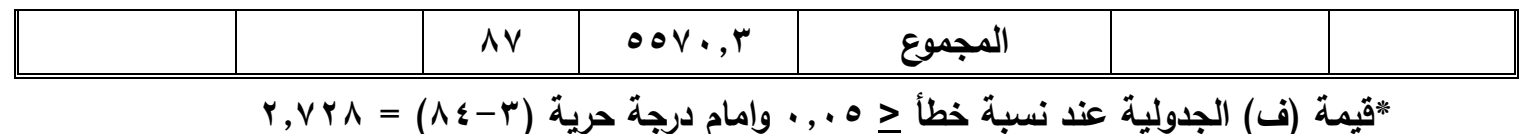

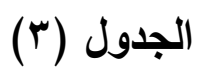

تحليل التباين بين مجموعات البحث الاربع في الاختبار القبلي لمهارل كرة السلة

\begin{tabular}{|c|c|c|c|c|c|}
\hline قيمة (ف) & المربعات & لدرجية & المربعات & مصدر التباين & المتغيرات \\
\hline \multirow{3}{*}{ 1,ro } & $\varepsilon Y, Y$ & $r$ & $I r v, \Lambda$ & بين المجموعات & \multirow{3}{*}{ لدرية التمريرة } \\
\hline & $r, 0$ & $\Lambda \varepsilon$ & $r T \leqslant 0, r$ & داخل المجموعات & \\
\hline & & $\Lambda V$ & rVVr,l & المجموع & \\
\hline \multirow{3}{*}{$1, \leqslant 0$} & $\cdot, \wedge 00$ & $r$ & Y,074 & بين المجموعات & \multirow{3}{*}{ الطبطبة } \\
\hline &., $0 \wedge 1$ & $\Lambda \varepsilon$ & $\leqslant 9, \varepsilon \uparrow \wedge$ & داخل المجموعات & \\
\hline & & $\Lambda V$ & $01,99 \leq$ & المجموع & \\
\hline \multirow{3}{*}{$1, r$} & $0, \cdot \varepsilon$ & $r$ & $10,1 r$ & بين المجموعات & \multirow{3}{*}{ التبات (درجة) التصويب من } \\
\hline & $r, \wedge V$ & $\Lambda \varepsilon$ & rro,o. & داخل المجموعات & \\
\hline & & $\Lambda V$ & $r \varepsilon, \pi r$ & المجموع & \\
\hline
\end{tabular}

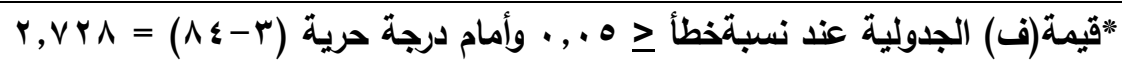

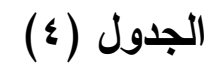

تحليل التباين بين مجموعات البحث الاريع في اختبارات عناصر اللياقة البدنية والحركية

\begin{tabular}{|c|c|c|c|c|c|}
\hline قيمة (ف) & متوسط المربعات & الحرجية & المربعات & مصدر التباين & المتغيرات \\
\hline \multirow{3}{*}{$1, . \varepsilon$} & ת & $r$ & •, \&^V & بين المجموعات & \multirow{3}{*}{ السرعة الانتقالية (ثانية) } \\
\hline &., 104 & $\Lambda \varepsilon$ & |r,IM1 & داخل المجموعات & \\
\hline & & $\Lambda V$ & 14,711 & المجموع & \\
\hline \multirow{3}{*}{ r, ro } & . $ו \wedge r q$ & $r$ &., $0 \leqslant \wedge 4$ & بين المجموعات & \multirow{3}{*}{ القوة الانفجارية للاطراف } \\
\hline & r., & $\Lambda \varepsilon$ & T,AYVT & داخل المجموعات & \\
\hline & & $\Lambda V$ & V,rVTr & المجموع & \\
\hline \multirow{3}{*}{ r, rA } & •, , Arr & $r$ &.,$r \leqslant 99$ & بين المجموعات & \multirow{3}{*}{$\begin{array}{c}\text { القوة الانفجارية للاطراف (متر) } \\
\text { السفلى }\end{array}$} \\
\hline & .,. & $\wedge \varepsilon$ & $r, \cdot V r V$ & داخل المجموعات & \\
\hline & & $\Lambda V$ & T,TYYT & المجموع & \\
\hline \multirow{3}{*}{ r, 14} & ro & $r$ & $14, .0$ & بين المجموعات & \multirow{3}{*}{ المرونة (سنتيمتر) } \\
\hline & $r, \& \wedge$ & $\Lambda \varepsilon$ & $r \cdot v, q 1$ & داخل المجموعات & \\
\hline & & AV & YYM,90 & المجموع & \\
\hline \multirow{3}{*}{$1, \times 4$} & $1,1 \cdot v$ & $r$ & r,rr. & بين المجموعات & \multirow{3}{*}{ الرشاقة (ثانية) } \\
\hline & 偌 & $\Lambda \varepsilon$ & 0,990 & داخل المجموعات & \\
\hline & & $\Lambda V$ & $04,+10$ & المجموع & \\
\hline
\end{tabular}

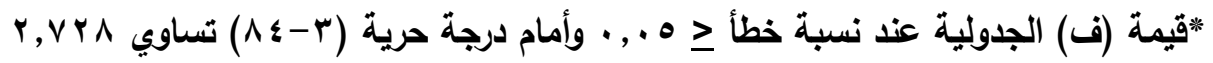




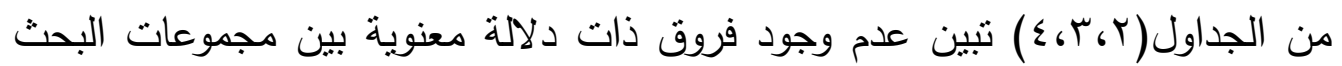
الاربع بما يشير الى تكافؤ مجموعات البحث في تلك المتغيرات . 
ب-ه التجربة الرئيسة للبحث :

تضمنت المناهج التعليمية لاسلوبي التضمين والامري ونموذجين من المجاميع الصغيرة

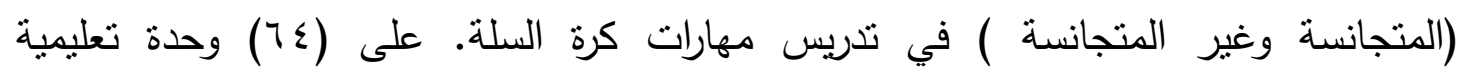
للمجموعات الاربع وهي كالآتي :

- المجموعة التجريبية الاولى : طبقت هذه المجموعة المنهاج التعليمي المقترح باستخدام

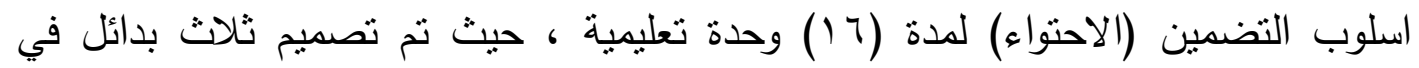

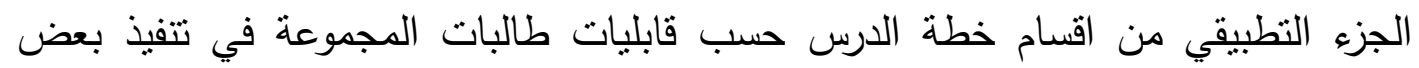
مهارات كرة السلة حيث يبنى هذا التصميم على أساس تنويع العوامل الخارجية والداخلية المتعلقة بالمهارة المراد تعلمها مراعيا التنرج في مستوى الصعوبة للواجب الحركي (التمرين)

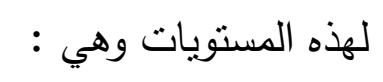

- التغيير في المسافات اثثاء (التمرير ، الطبطبة ، التصويب) .

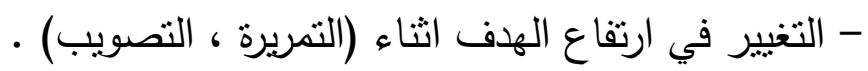

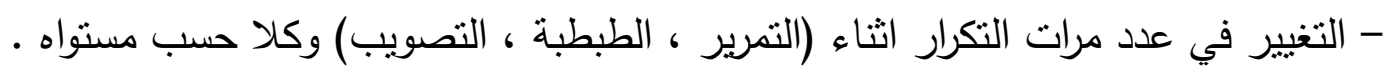

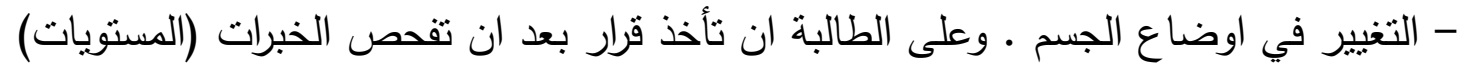

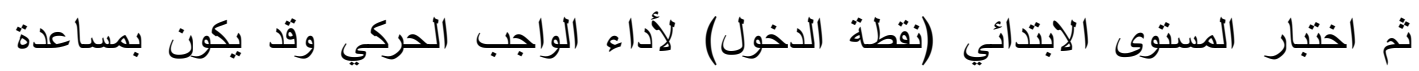
المدرسة ثم تصحح اخطاءها بمقارنة ادائها بورقة العمل التي بحوزتها ثم لها الحق في الخاء التاذ

$$
\text { - تخرار نفس العمل . }
$$

- اختيار مستوى أدنى .وبهذا تستمر العملية التعليمية وفق ما ذكر سابقا حتى انتهاء الوقت

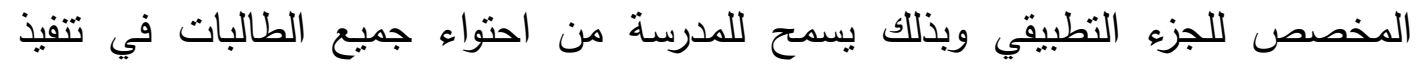

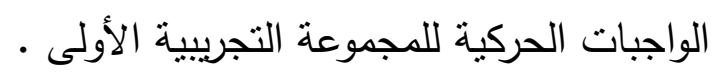

- المجموعة التجريبية الثانية : طبقت هذه المجوعة المنهاج التعليمي المقترح باستخدام اسلوب المجاميع الصغيرة (متجانسة التحصيل) لمدة (7 (1) وحدة تعليمية ، إذ تم تقسيم

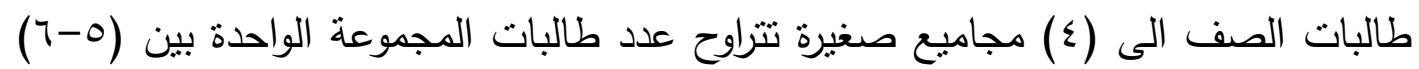
طالبة، وتكون افراد كل مجموعة صغيرة ذات مستوى واحد متجانسة في القدرات المهارية ،

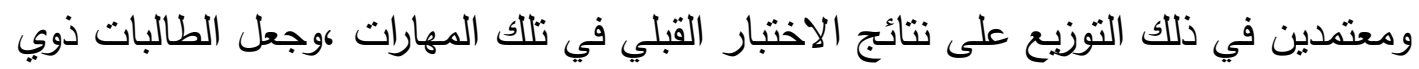

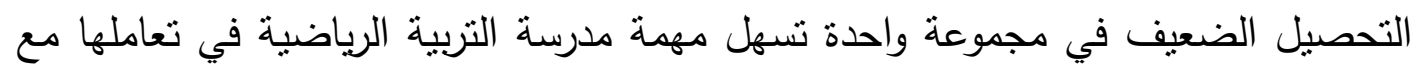
طالبات منقاربات في المستوى المهاري وتمكنها من تهيئة الخبرات والنشاطات لكل 
مجموعة .وتكلف طالبة واحدة لتكون قائدة المجموعة ومسؤولة على تحركات افراد مجموعتها

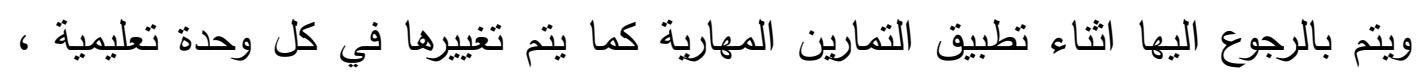

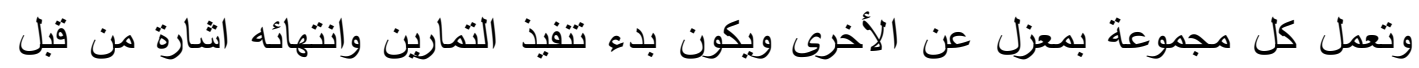

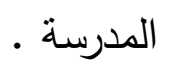

- المجموعة التجريبية الثالثة : طبقت هذه المجموعة المنهاج التعليمي المقترح باستخدام

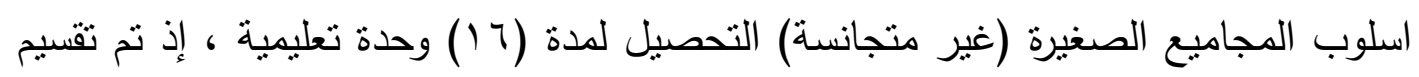

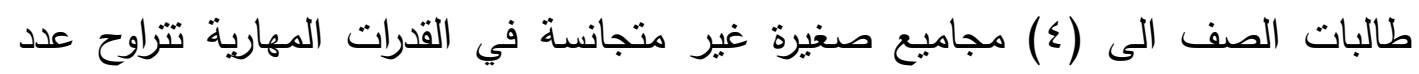

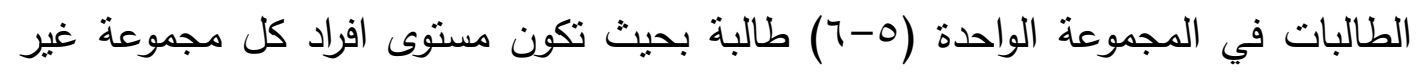

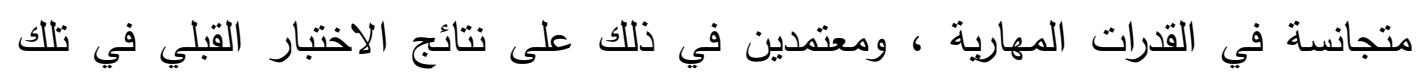

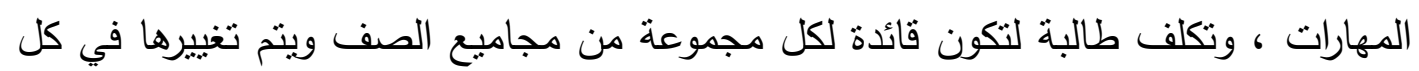

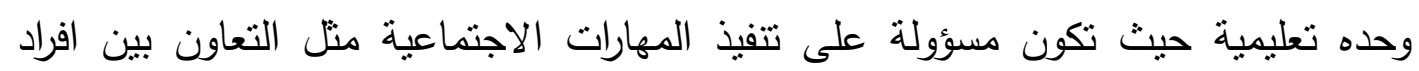

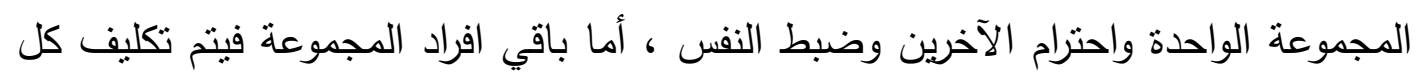

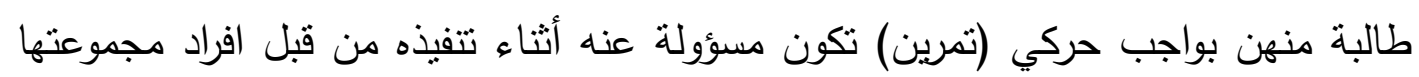

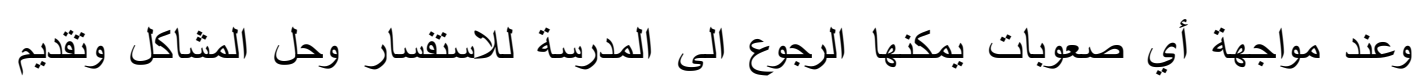

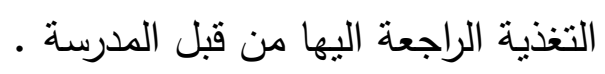
- المجموعة التجريبية الرابعة : طبقت هذه المجموعة اسلوب التدريس الامري لمدة (7 المبة ه ( ) وحدة

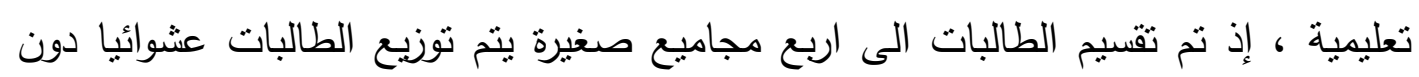

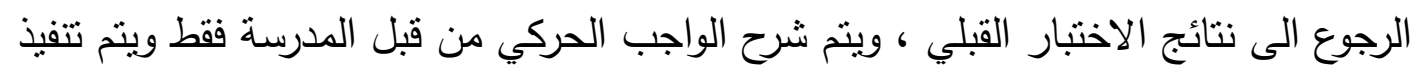
التمارين التطبيقية في وقت واحد لكل مجموعة بحيث تكون المدرسة هي المسؤولة على توجيه

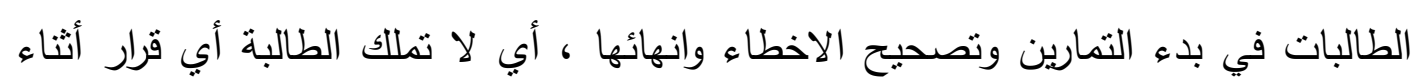

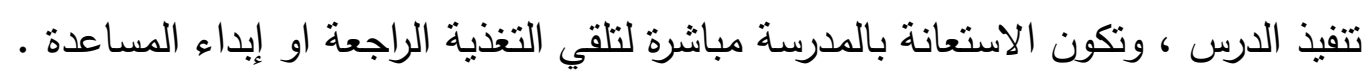

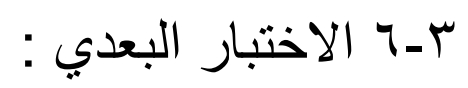

بعد الانتهاء من تتفيذ التجربة الرئيسة طبقت الاختبارت البعدية على طالبات مجموعات

$$
\text { البحث الاربع وبنفس ترتيب الاختبارات القبلية. }
$$

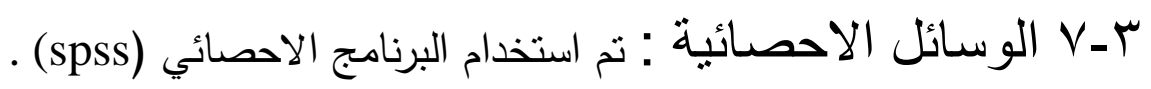


ع - عرض نتائج بعض مهار ات كرة السلة ومناقنتها :

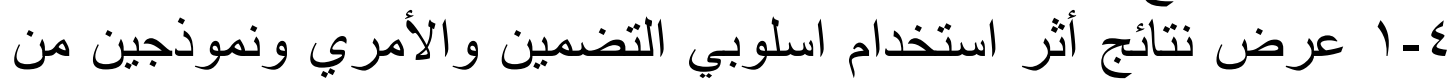

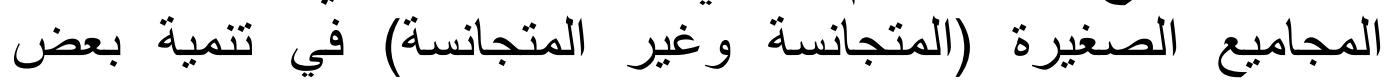

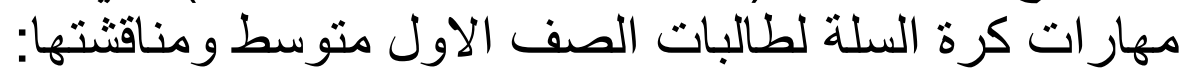

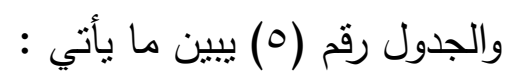

\section{(0) الجدول}

يبين المؤثرات الاحصائية للاختبارين القبلي والبعدي في تطوير بعض المهارات الأساسية بكرة السلة لمجموعات البحث الأريع

\begin{tabular}{|c|c|c|c|c|c|c|c|}
\hline المحتسبة & $\varepsilon+$ & سن & الاختبار & والقياس & اسم الاختبار & الأسهاراتية & ت \\
\hline \multirow{2}{*}{ *I T.0 } & $7 . \wedge \mu$ & rr... & قبلي & \multirow{2}{*}{ درجة } & \multirow{2}{*}{ الصدة التمريرة } & \multirow{2}{*}{ الصدريرة التمرية } & \multirow{6}{*}{ التضوبن } \\
\hline & r... & $\leqslant 1.90$ & بعدي & & & & \\
\hline \multirow{2}{*}{$* 1 . . v \varepsilon$} & .700 & ג.r. & قبلي & \multirow{2}{*}{ ثانية } & الطبطبة المستقيمة & \multirow{2}{*}{ الطبنقيمة } & \\
\hline &.$\Sigma T r$ & $7.0 \leq$. & بعدي & & لمسافة7 (م & & \\
\hline \multirow{2}{*}{ *. } & $r . T^{\prime}$ & $r . \wedge Y$ & قبلي & \multirow{2}{*}{ درجة } & التهديف على بعد & \multirow{2}{*}{ التهديف من الثبات } & \\
\hline & $1 . V \cdot$ & 5.90 & بعدي & & ع عن السلة & & \\
\hline \multirow{2}{*}{$* q . \leq}$. & 0.71 & $19 . V 4$ & قبلي & \multirow{2}{*}{ درجة } & دقة التمريرة & \multirow{2}{*}{ الصدريرة الصدرية } & \multirow{6}{*}{ الملبوب المجنبع } \\
\hline & $V . \Sigma Y$ & $r \wedge . \leqslant 0$ & بعدي & & الصدرية & & \\
\hline \multirow{2}{*}{ *0. } &.$\wedge I V$ & ᄉ.Y9r & قبلي & \multirow{2}{*}{ ثانية } & الطبطبة المستقيمة & \multirow{2}{*}{ المستقبمة } & \\
\hline & $.00 Y$ & V.11. & بعدي & & لمسافة7 (م & & \\
\hline \multirow{2}{*}{ *†. M } & 5.19 & $Y . V T$ & قبلي & \multirow{2}{*}{ درجة } & التهديف على بعد & \multirow{2}{*}{ التهديف من } & \\
\hline & 1.21 & T.YT & بعدي & & عم عن السلة & & \\
\hline \multirow{2}{*}{$* V .91$} & 0.94 & Tr.TE & قبلي & \multirow{2}{*}{ درجة } & دقة التمريرة & \multirow{2}{*}{ الصدريزة } & \multirow{6}{*}{ السلوب المجاميع } \\
\hline & 0.79 & MV.O. & بعدي & & الصدرية & & \\
\hline \multirow{2}{*}{ סמ.tה } &.$V I T$ & ᄉ. $1 \leq 7$ & قبلي & \multirow{2}{*}{ ثنانية } & الطبطبة المستقيمة & \multirow{2}{*}{ المستقبمة الطبة } & \\
\hline &.$V \wedge r$ & 8.717 & بعدي & & لمسافة7 (م & & \\
\hline \multirow{2}{*}{$* \eta \cdot r$} & $Y .0$ & Y.1 $\varepsilon$ & قبلي & \multirow{2}{*}{ درجة } & التهديف على بعد & \multirow{2}{*}{ التهديف من الثبات } & \\
\hline & 1.rY & $0 . Y V$ & بعدي & & ع ع عن السلة & & \\
\hline \multirow{2}{*}{$* Y .0$. } & $\varepsilon . r$ & $r \cdot . \Sigma 1$ & قبلي & \multirow{2}{*}{ درجة } & دقة التمريرة & التمريرة & \\
\hline & $\varepsilon .7$ & $r M \leq 0$ & بعدي & & الصدرية & الصدرية & \\
\hline lor & .771 & $\Lambda . \leqslant 7 \Lambda$ & قبلي & ثخان.اة & الطبطبة المستقيمة & الطبطبة & أسلوب \\
\hline 1.01 &..$V \cdot 7$ & $1.10 \leqslant$ & بعدي & كابيه & لمسافة7 (م & المستقيمة & أمري \\
\hline $1 \mathrm{dV}$ & 1.07 & $1 . \wedge r$ & قبلي & (1) & التهديف على بعد & التهديف من & \\
\hline & $1.1 \varepsilon$ & r.09 & بعدي & درجه & عم عن السلة & الثبات & \\
\hline
\end{tabular}

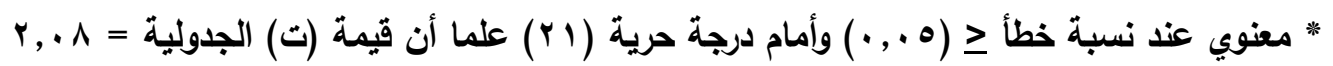


ا ـ وجود فروق ذات دلالة معنوية بين متوسطات درجات الاختبارين القبلي والبعدي في جميع دأل

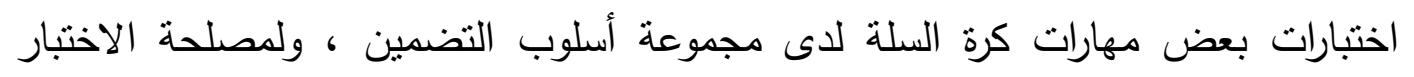
البعدي • ويعزى سبب ذلك إلى ان اسلوب التضمين قد راعى الفروق الفردية فوظف المهارة

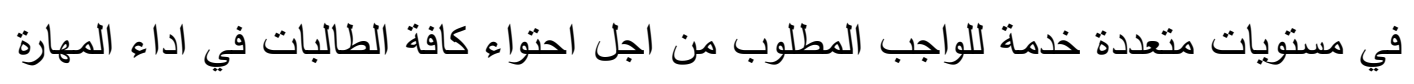

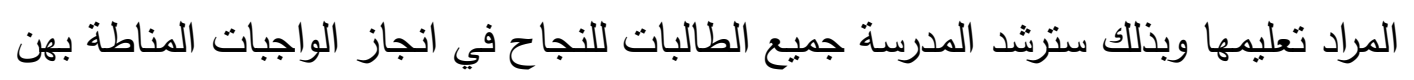

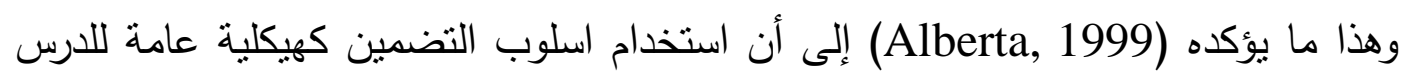

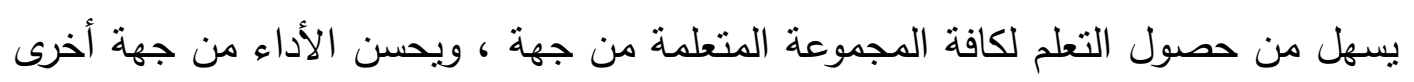

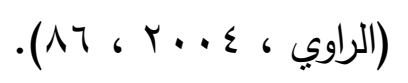
r. وجود فروق ذات دلالة معنوية بين متوسطات درجات الاختبارين القبلي والبعدي في جميع

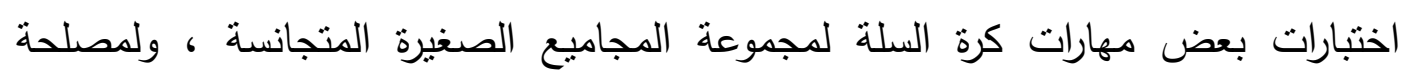

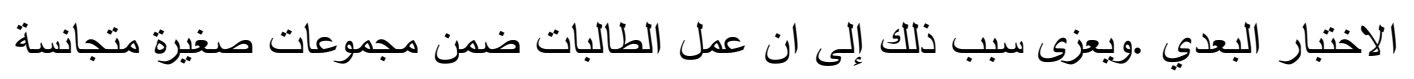

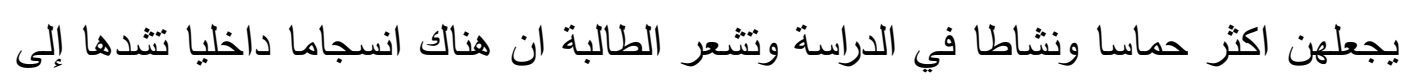

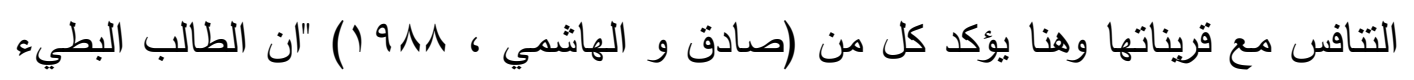

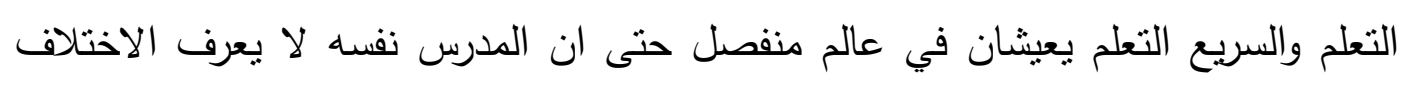

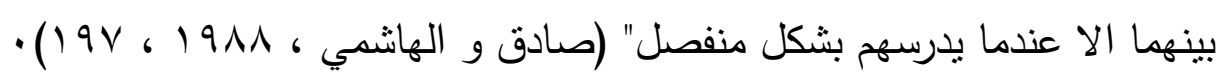

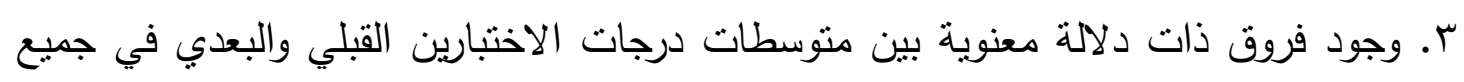

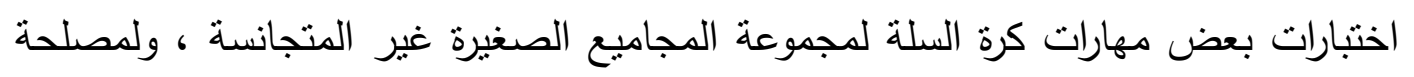

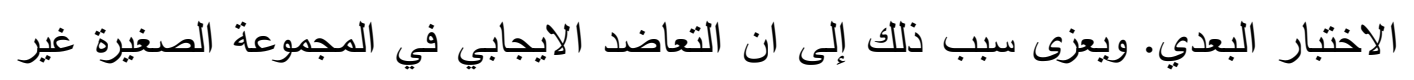

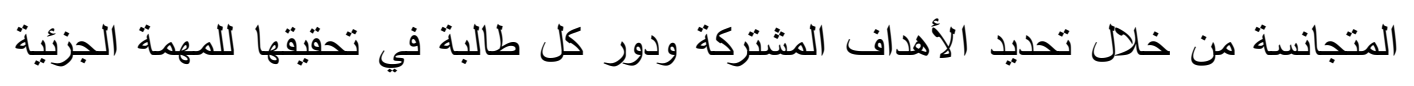

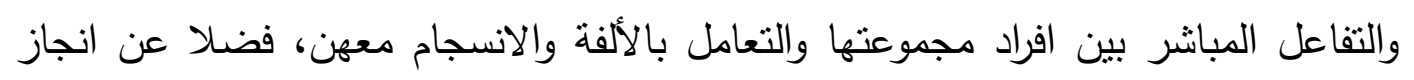

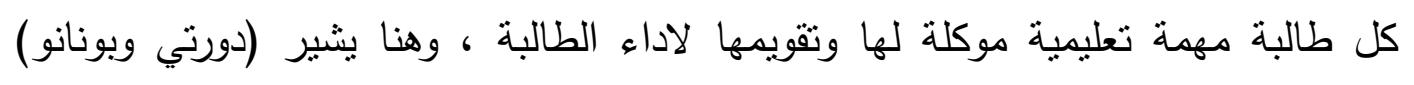
(Dorgherty \& Bonanno)

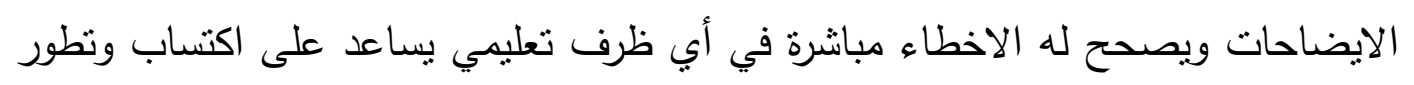

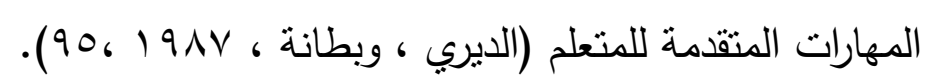

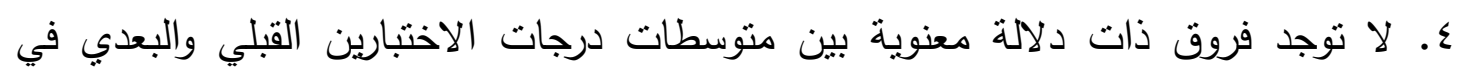

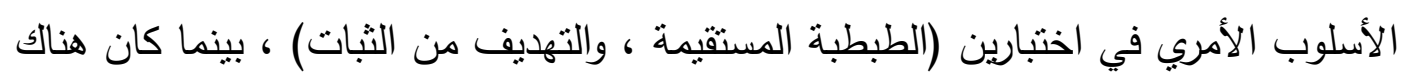

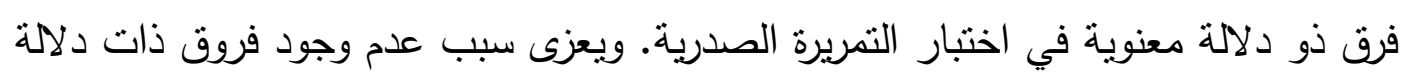
معنوية في الاختبارين القبلي والبعدي لمهارتي (الطبطبة المستقيمة ، والتهديف من التبار التبرئ

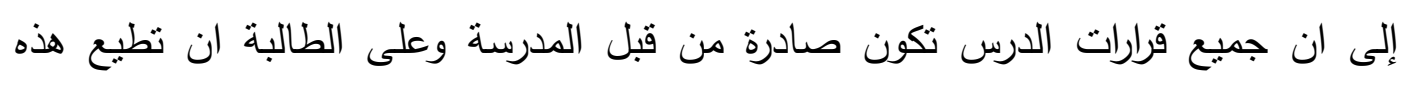

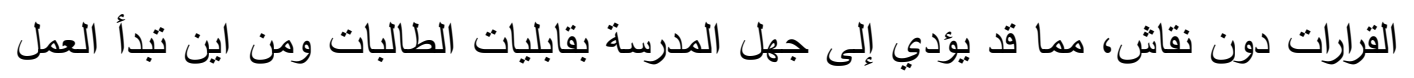


معهن وعدم مراعاة الفروق الفردية بينهن وبالتالي قلة روح التعاون والحماس بين مجاميع

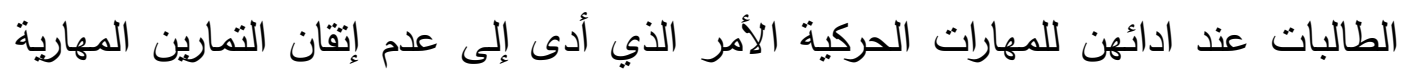

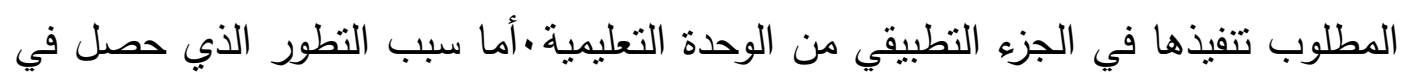

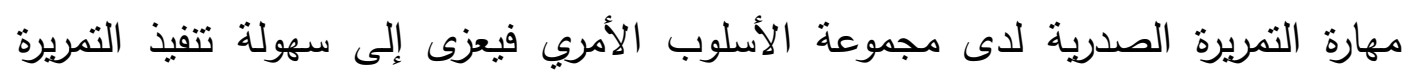

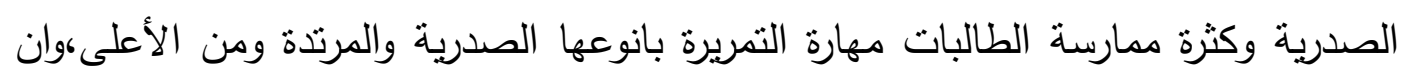
التمريرة الصدرية من أسهل التمريرات وتؤدى بدون صعوبة .(حمودات واخرون ، 1910 ، 1910

ع - عرض نتائج المقارنة بين أثز استخدام اسلوبي التضمين والأمري

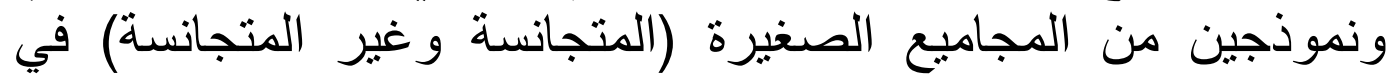

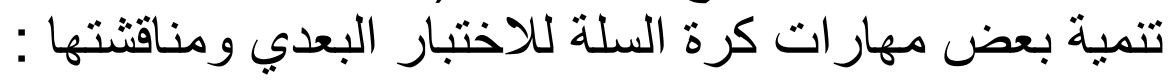

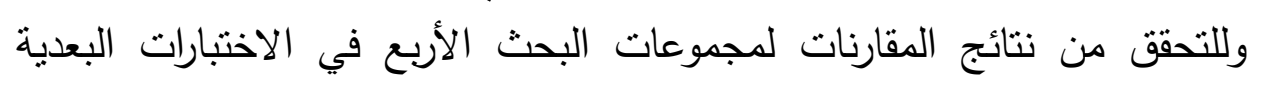
استخدم تحليل التباين باتجاه واحد والجدول رقم (؟) يبين ذلك :

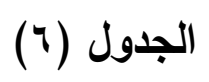

تحليل التباين بين مجموعات البحث الأربع في الاختبارل البعدية في بعض

مهارات كرة السلة

\begin{tabular}{|c|c|c|c|c|c|}
\hline قيمة فـ المحتسبة & متوسط المربعات & الحرية & مجموع المريعات & مصدر التباين & الاختبارات \\
\hline \multirow{3}{*}{ * } & $1 \leq 7 Y, 1 \% 4$ & $r$ & $\leqslant$ \& & بين المجموعات & \multirow{3}{*}{ دقة الصدريرة } \\
\hline & $r \wedge, r \cdot v$ & $\Lambda \varepsilon$ & צ צו, צ'q & داخل المجموعات & \\
\hline & & $\Lambda \vee$ & $T \vee \Delta 0, \vee \vee r$ & المجموع & \\
\hline \multirow{3}{*}{ *YY,OrI } & $1 \cdot, \leqslant 91$ & $r$ & $r^{M}, \leq q \leq$ & بين المجموعات & \multirow{3}{*}{ 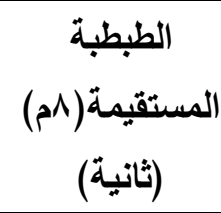 } \\
\hline & • & $\wedge \varepsilon$ & גr, & داخل المجموعات & \\
\hline & & $\wedge \vee$ & $T \leq, V M Y$ & المجموع & \\
\hline \multirow{3}{*}{ 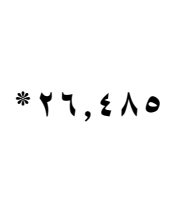 } & Or, \&94 & $r$ & $10 \vee, \leqslant \wedge 9$ & بين المجموعات & \multirow{3}{*}{ التهديف من } \\
\hline & $1,9 \wedge r$ & $\Lambda \varepsilon$ & $174,0 \ldots$ & داخل المجموعات & \\
\hline & & $\wedge \vee$ & $r r r, q \wedge q$ & المجموع & \\
\hline
\end{tabular}

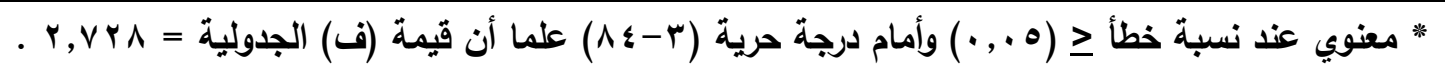


يتبين من الجدول رقم (؟) ان جميع قيم (ف) المحتسبة لاختبارات البعدية المختارة

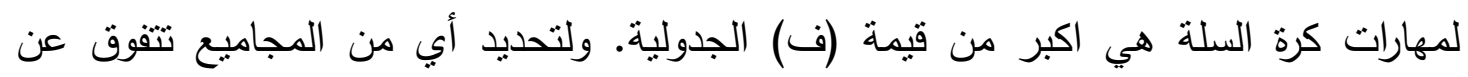

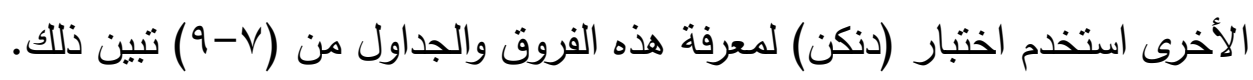

(V) الجدول

اختبار دنكن لمقارنة متوسطات اختبار دقة التمريرة الصدرية بكرة السلة

حسب مجاميع البحث الأربع

\begin{tabular}{|c|c|c|c|c|c|}
\hline 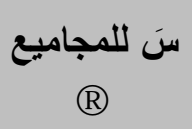 & 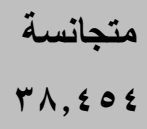 & غير متجانسة & ع الأمري & L.S.R. & سَ للمجاميع \\
\hline & $* \mu, 0$ & $* \leqslant, \leqslant$ \& & $* 1 \wedge, 0$ & $r, \leqslant$ ४ & 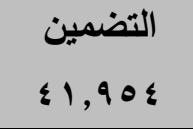 \\
\hline & & •, 90 \& & $* 10$ & r & 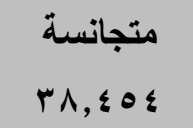 \\
\hline & & & $1 \leqslant, ., 4$ & $r, \mid \Lambda \varepsilon$ & غير متجانسة \\
\hline
\end{tabular}

* معنوي عذ نسبة خطأ > (0., )

يتبين من الجدول رقم (V) المقارنة بين متوسطات نتائج اختبار دقة التمريرة الصدرية بكرة السلة وحسب مجاميع البحث الأربع ، فقد تبين :

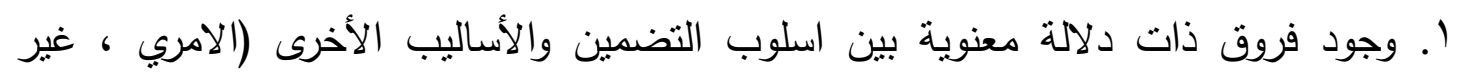

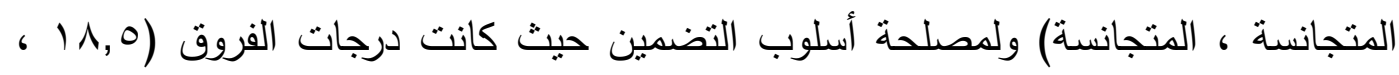
ـ

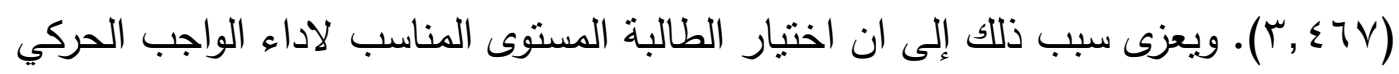

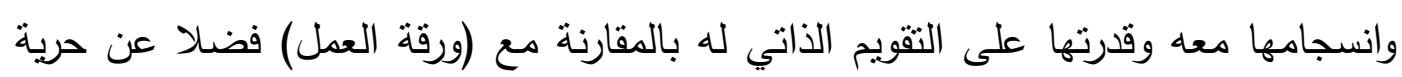

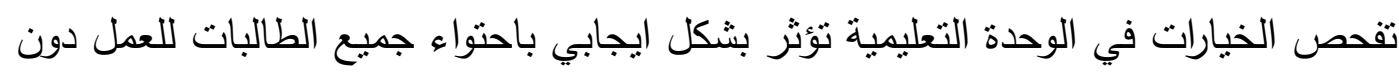

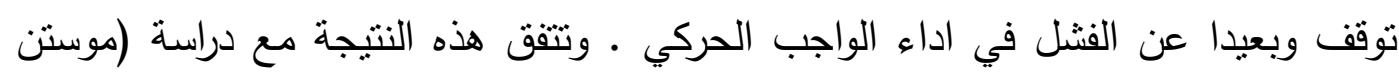

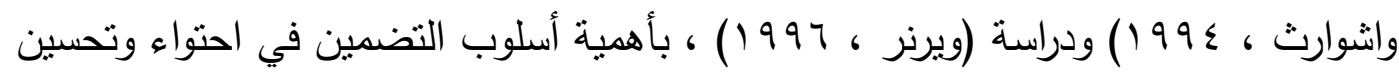

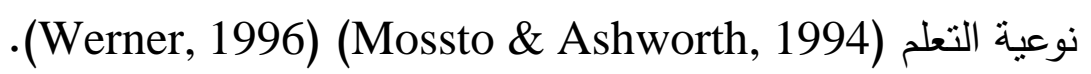
r. وجود فروق ذات دلالة معنوية بين اسلوبي المجاميع الصغيرة (المتجانسة ، وغير المتجانسة)

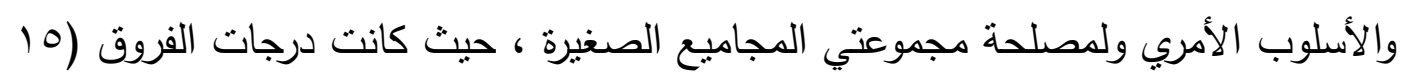

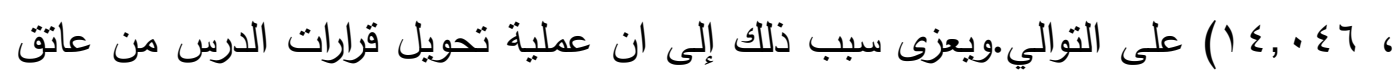


الددرسة إلى مسؤولية الطالبة والوضوح المسبق لاهداف الدرس لدى الطالبات وتحديدها في

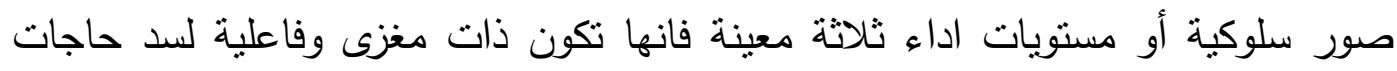

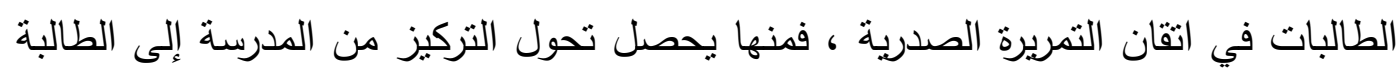

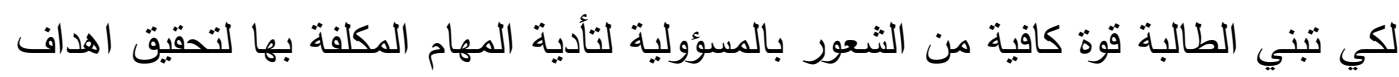

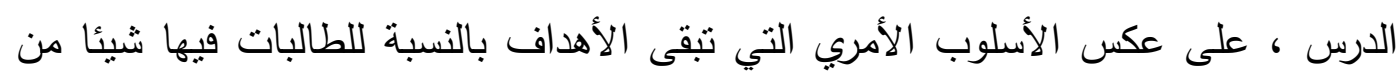

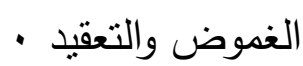
r. لا توجد فروق ذات دلالة معنوية بين اسلوبي المجاميع الصغيرة (المتجانسة ، وغير

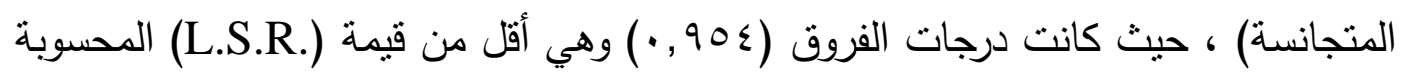

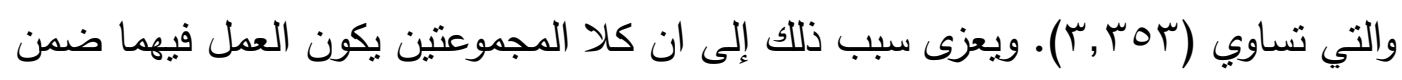

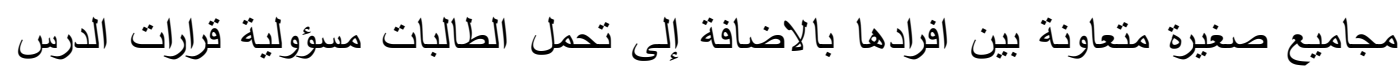

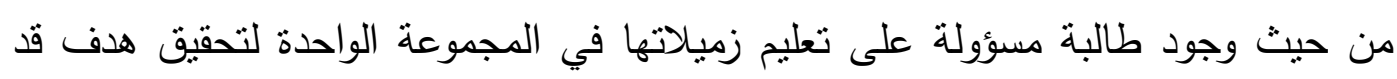

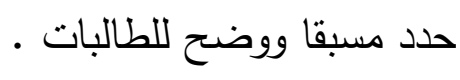

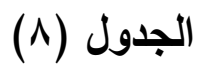

اختبار دنكن لمقارنة متوسطات اختبار الطبطبة المستقيمة بكرة السلة

حبب مجاميع البحث الأريع

\begin{tabular}{|c|c|c|c|c|c|}
\hline سَ للمجاميع & غير متجانسة & $\begin{array}{l}\text { متجانسة } \\
\text { v, 11 }\end{array}$ & تضمين & L.S.R. & سَ للمجاميع \\
\hline & $*$, , OrA & $* 1, . \leq \leq$ & $* 1,71 \leq$ & $\cdot, \leqslant 1$. & الأمري \\
\hline & & $*, 0.7$ & $* 1, . \vee V 7$ & $\cdot, r q v$ & غير متجانسة \\
\hline & & & $*,, \circ V$ & $\cdot, r v v$ & $\begin{array}{l}\text { متجانسة } \\
\text { v, 1 }\end{array}$ \\
\hline
\end{tabular}

يبين الجدول رقم (^) المقارنة بين منوسطات نتائج اختبار الطبطبة المستقيمة بكرة السلة

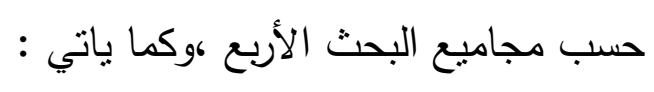

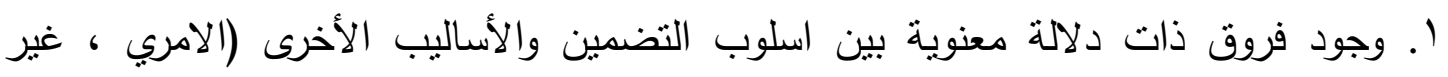

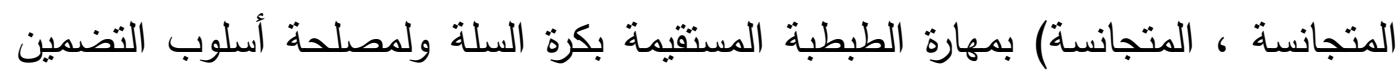

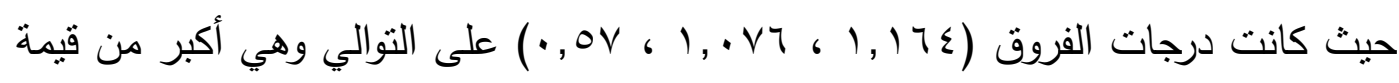
(L.S.R.)

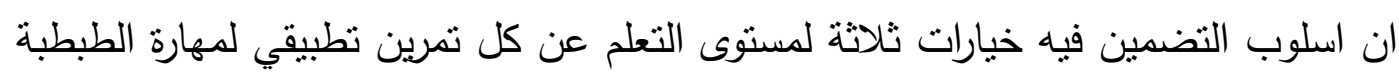


واعتماد الطالبة في اتخاذ المستوى المناسب لقابليتها الأمر الذي ادى إلى انجاز واجبها

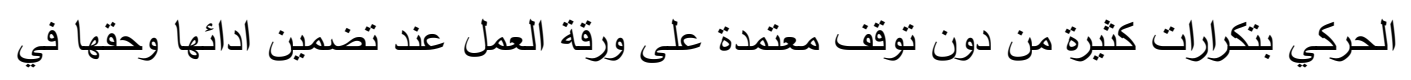

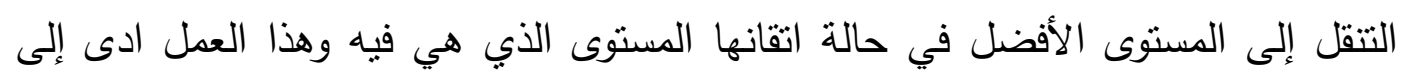

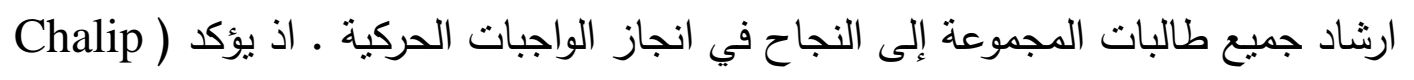
(et. al., 1984

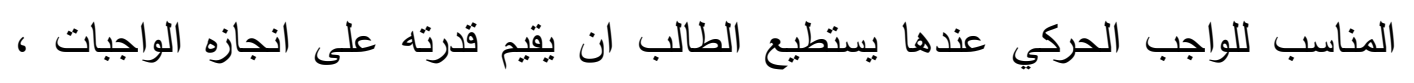

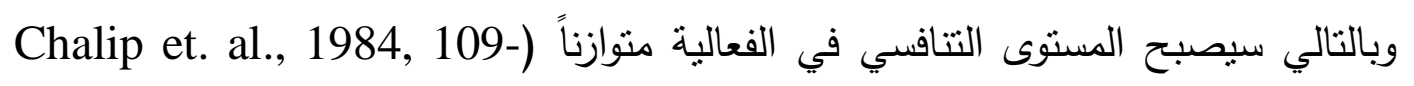

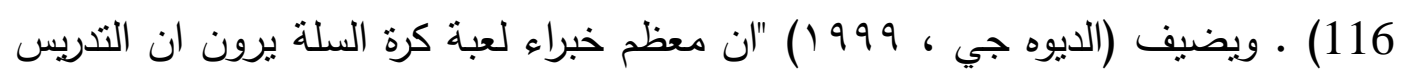

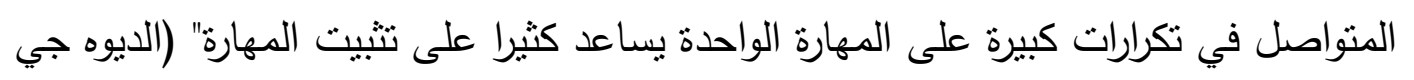
(1) ، 1999، r. وجود فروق ذات دلالة معنوية بين اسلوب المجموعة الصغيرة المتجانسة واسلوبي (الأمري ،

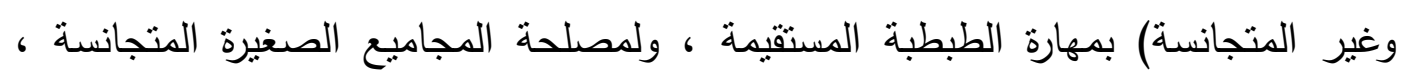

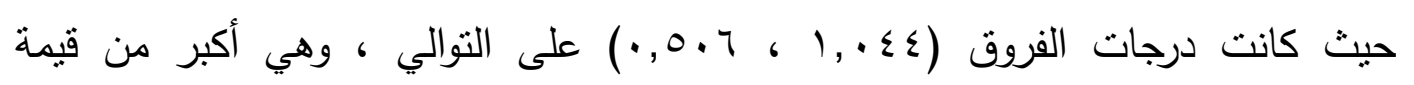
(L.S.R.)

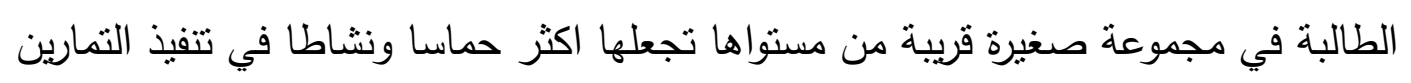

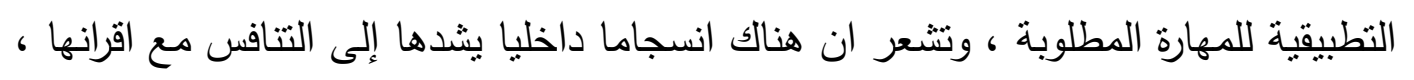

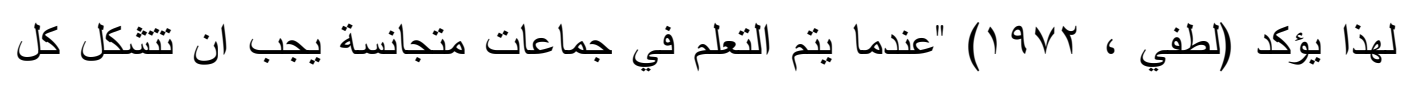

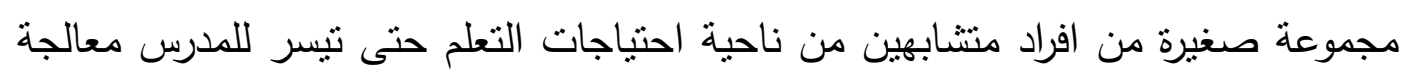

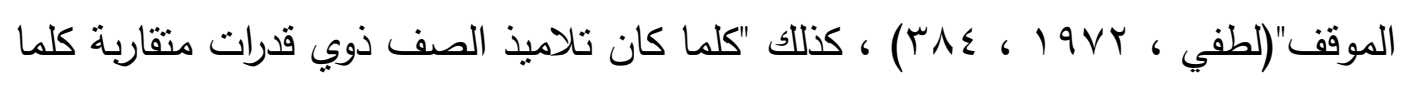

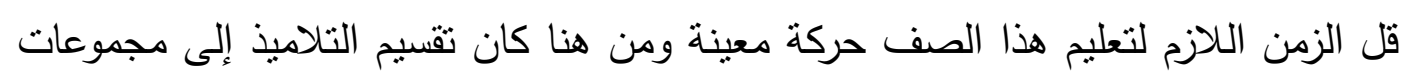

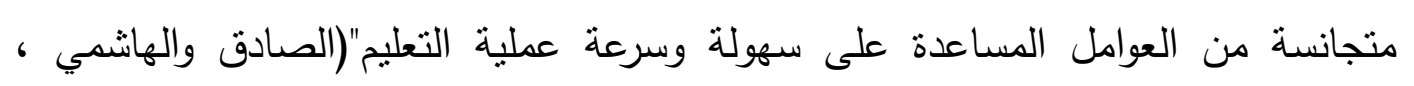

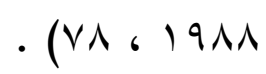

r. وجود فروق ذات دلالة معنوية بين اسلوب المجاميع الصغيرة غير المتجانسة والأمري

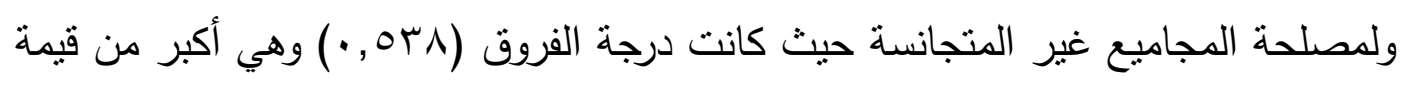
(L.S.R.)

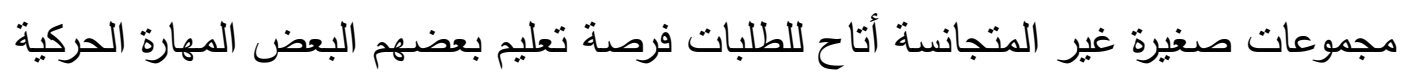

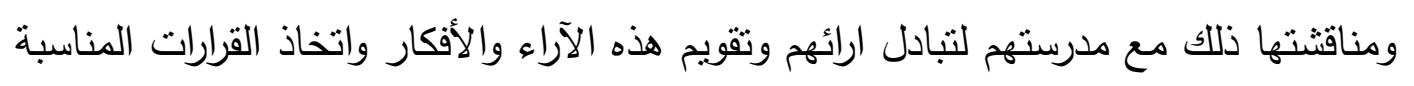

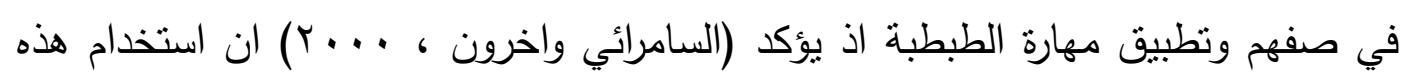

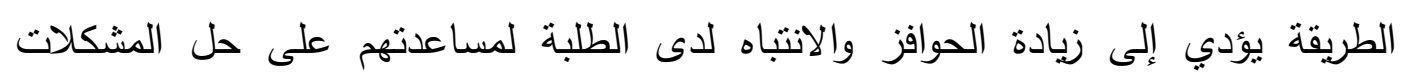

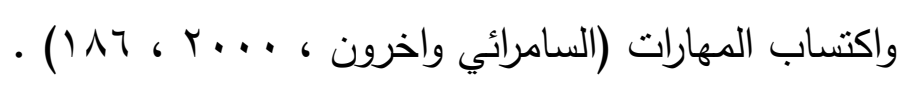




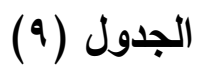

يوضح نتائج اختبار دنكن لمقارنة متوسطات اختبار التهديف من الثبات

حسب مجاميع البحث الأريع

\begin{tabular}{|c|c|c|c|c|c|}
\hline سَ للمجاميع & غير متجانسة & צ ه 9 , ؛ & 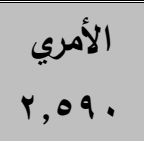 & L.S.R. & سَ للمجاميع \\
\hline & $*, 900$ & $* 1, r \vee r$ & $* r, T r V$ & $\cdot, 911$ & متجانسة \\
\hline & & גו & *r, rAr & $\cdot, \wedge \wedge \uparrow$ & غير متجانسة \\
\hline & & & *Y, & $\cdot, \wedge \leq \Gamma$ & عضمين \\
\hline
\end{tabular}

يتبين الجدول (9) المقارنة بين منوسطات نتائج اختبار التهديف من الثبات بكرة السلة

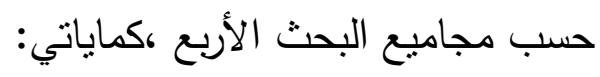
ا. وجود فروق ذات دلالة معنوية بين اسلوب المجموعة الصغيرة المتجانسة والأساليب (الامري،

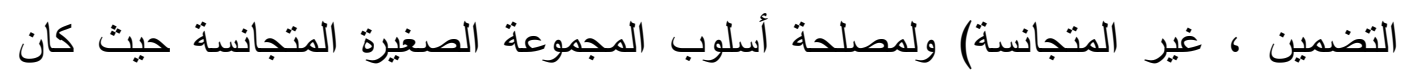

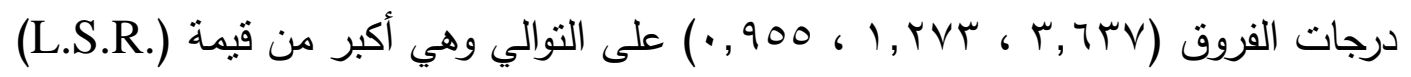

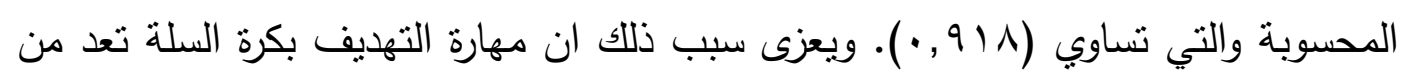

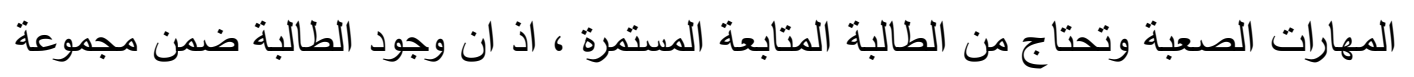

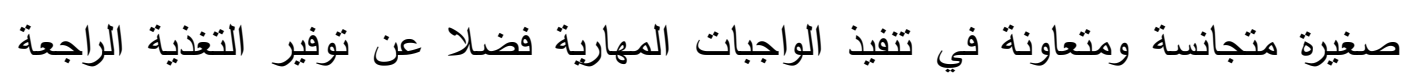
بمقارنة ادائها بورقة العمل ودور قائدة المجموعة في تقديم التغذية الراجعة الفورية والعمل

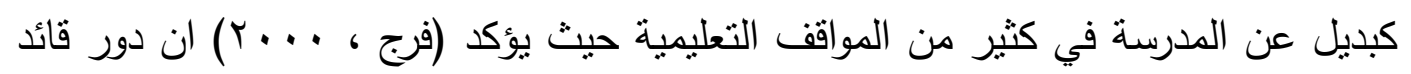

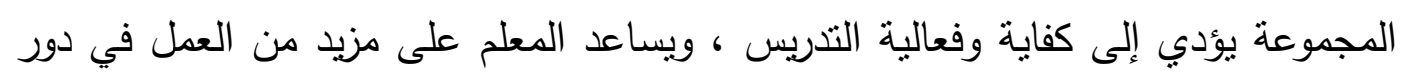

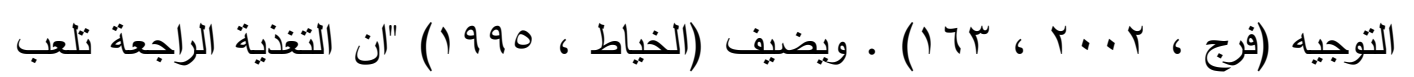

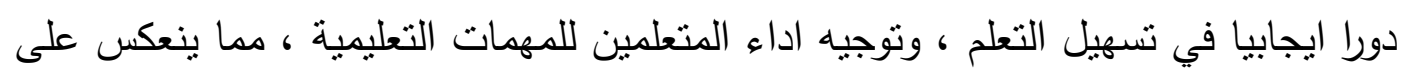

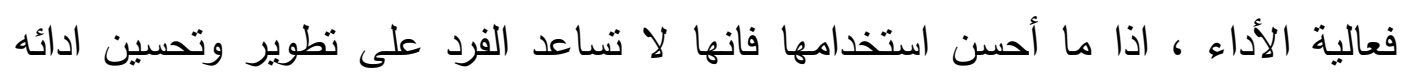

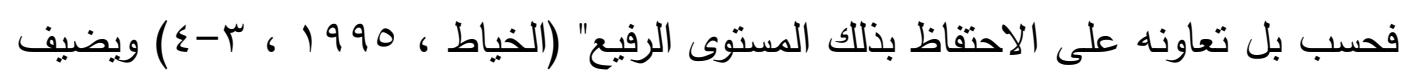

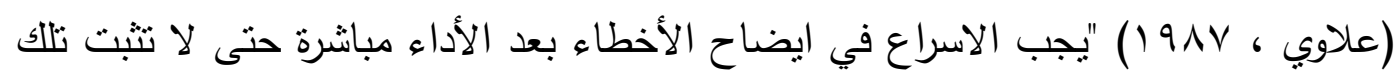

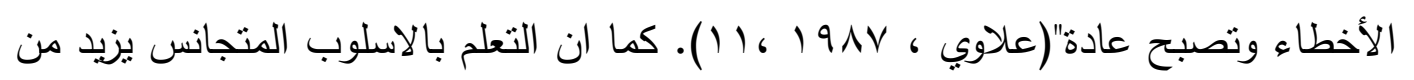


رغبة الطالب نحو التعلم وتتجع على التعاون فيما بينهم وكذللك الى ظهور القيادات بين

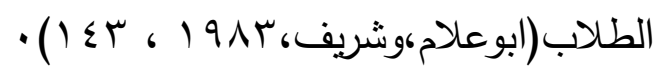

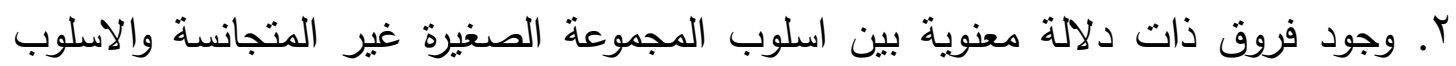

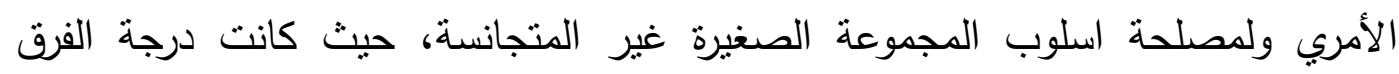

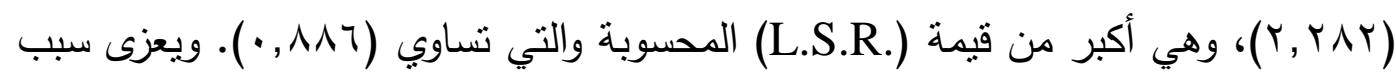

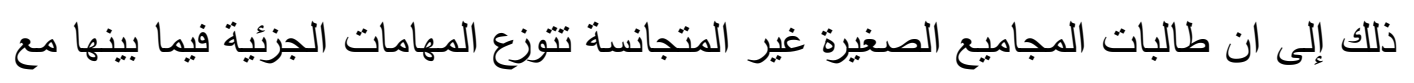

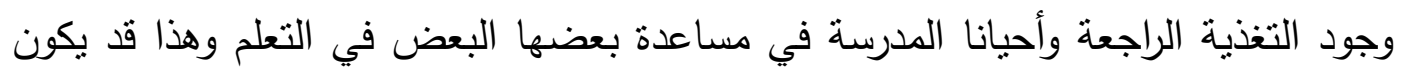

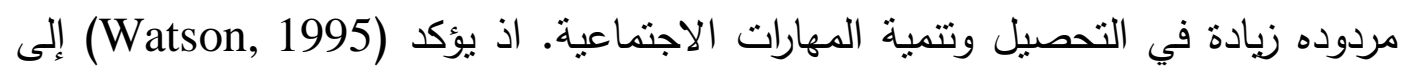

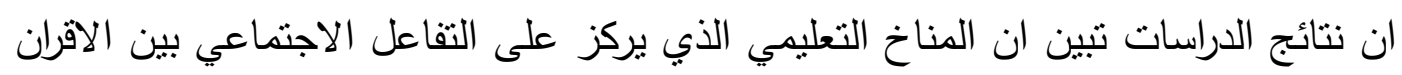
يؤثر ايجابيا في تحصيل الطلبة ومهاراتهم واتجاهاتهم (Watson, 1995, 210).

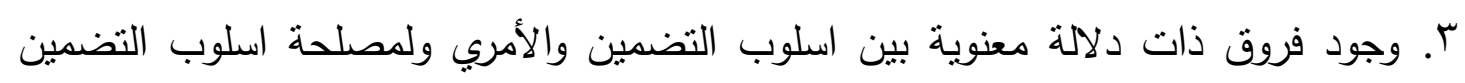

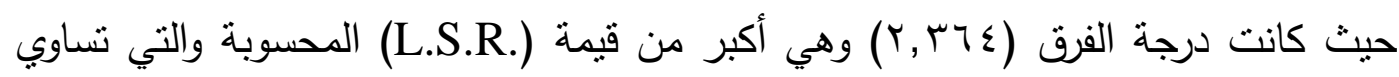

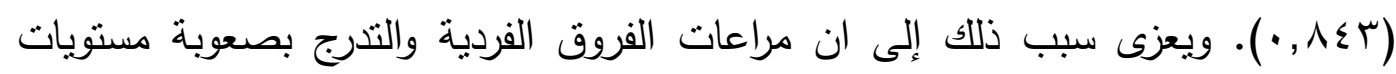

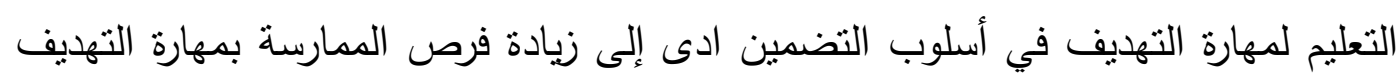

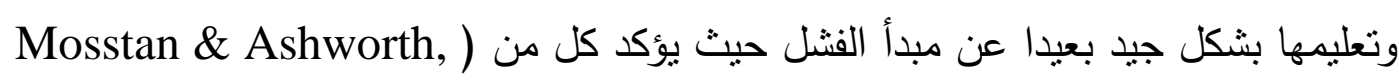

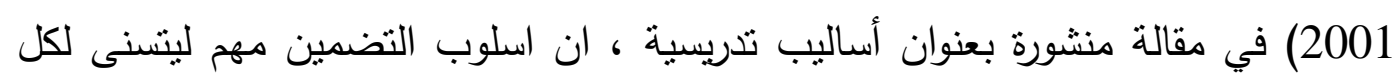

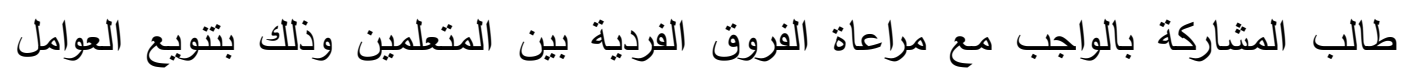

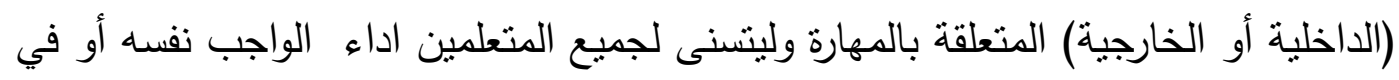

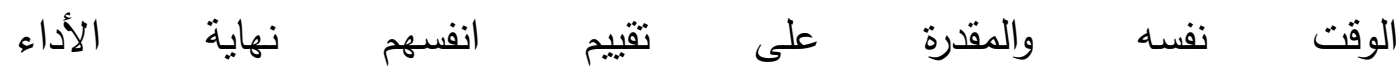

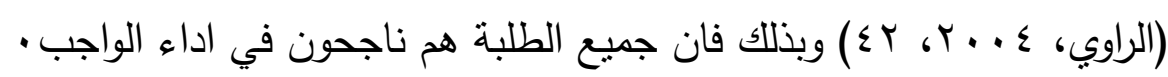


ا ـ حقق اسلوب التضمين ونموذجين من المجاميع الصغيرة (المتجانسة وغير المتجانسة) تتمية

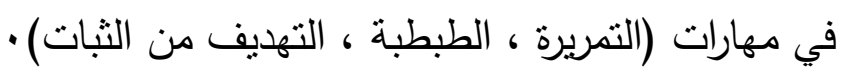

r. حقق الأسلوب الأمري تتمية في مهارة التمريرة الصدرية.

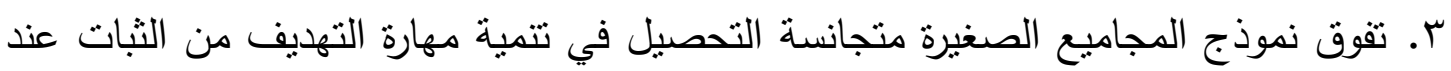

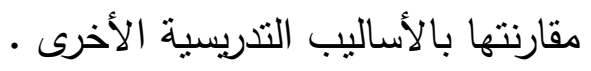

التوصبات و المقترحات :

ا. استخدام اسلوب التضمين ونموذجين من المجاميع الصغيرة لما لهم من تأثير ايجابي في : لتي

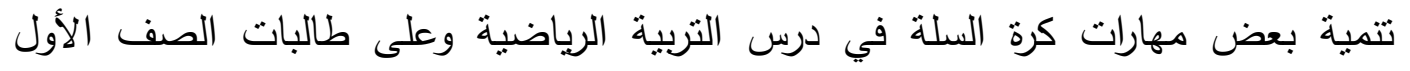
متوسط r. يمكن استخدام الاختبارات المهارية المعدلة من قبل الباحثان في اختبارات المهارات الأساسية بكرة السلة لمعالجة متغيرات اخرى ولمرحلة عمرية قيد هذه الدراسة .

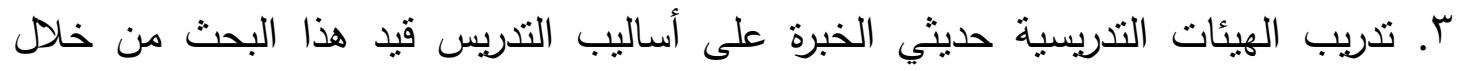

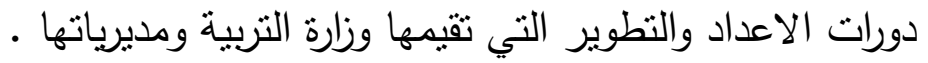

\section{المصادر العربية و الأجنبية:}

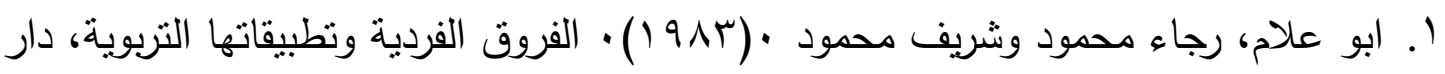

القلم ، كلية التربية ، جامعة الكويت .

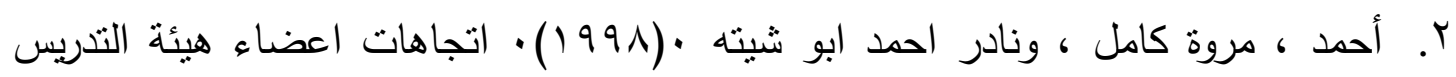

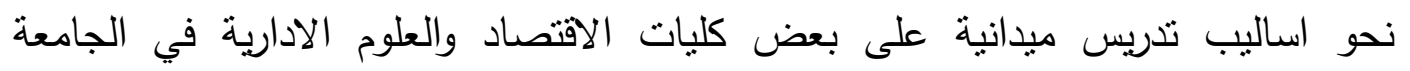

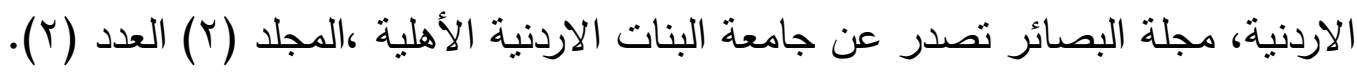

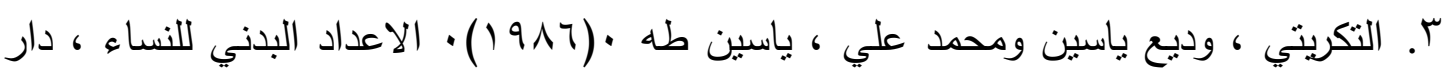
الكتب للطباعة والنشر ، جامعة الموصل.

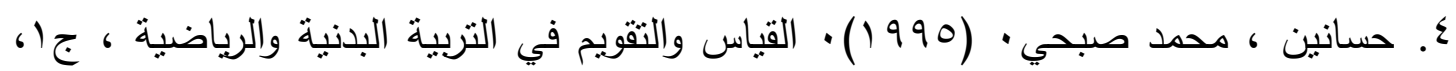
طب ، دار الفكر العربي ، القاهرة . ๑. حسن ، جمال صالح واخران • (1991) • تدريس الثربية الرياضية ، دار الكتب للطباعة

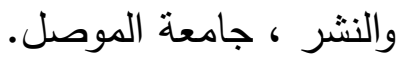
7. حسن ، سليمان علي واخران • (ז19 (1) • المبادئ التدريبية والخططية في كرة اليد ، دار الكتب للطباعة والنشر ، جامعة الموصل . 
V. حمودات ، فائر بشير واخران • (910) • اسس ومبادئ كرة السلة ، مطبعة جامعة

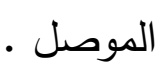

^. الحيلة ، محمد محمود • (999 ()) • التصميم التعليمي نظرية وممارسة ، دار المسيرة للنشر

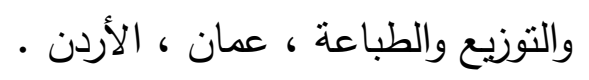
9 . خطاب ،محمد · (919 (1) • التعليم التعاوني داخل الاردن • ، الصف وخارجه ، دار التربية والتعليم ،

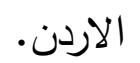

• 1. الخياط ، ضياء قاسم ( 1990 (1) • انز استخدام استراتيجتي التدريس بالاهداف والتغذية

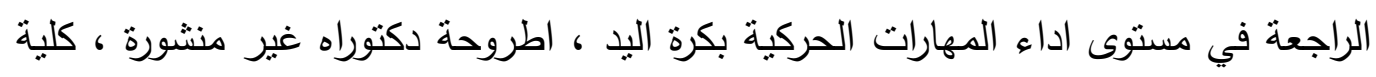

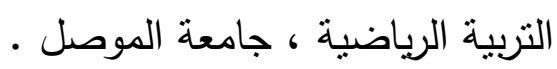

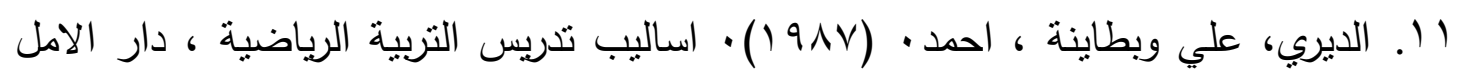

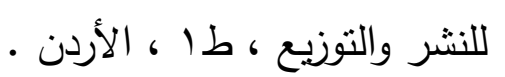
r ا. الديري ، علي ومحمد ، علي · (ب99 (1) • مناهج التربية الرياضية بين النظرية والنطبيق،

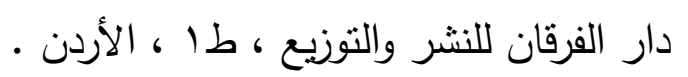

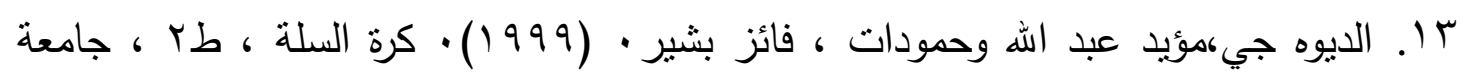
الموصل.

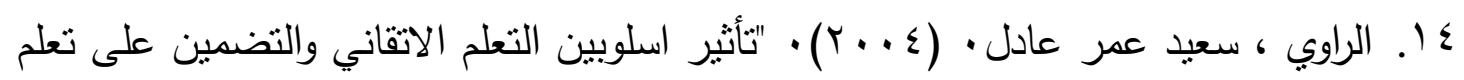

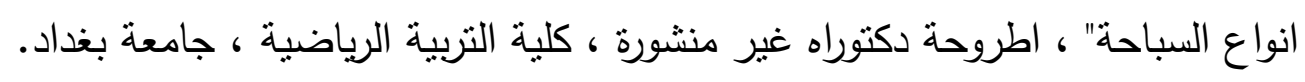

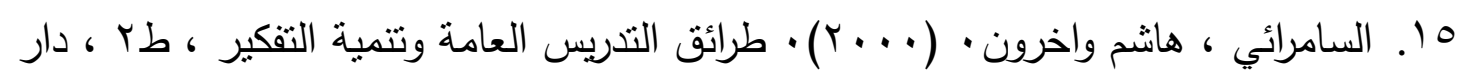

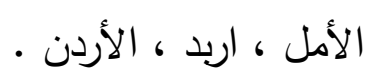

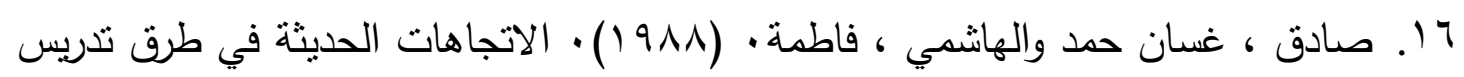

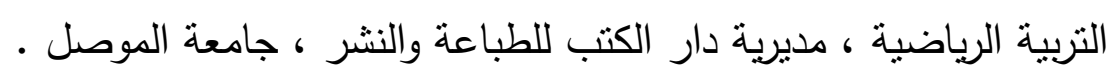

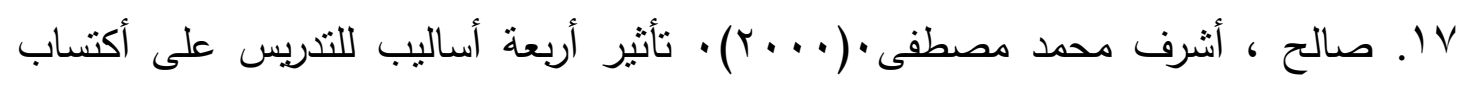

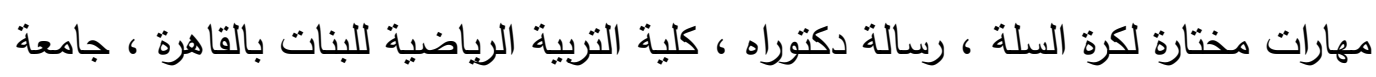
• حلوان

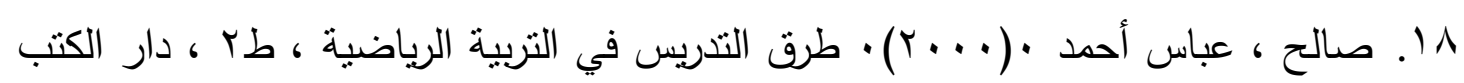

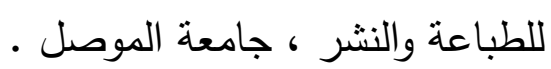
9 1. عبيدات ، سليمان أحمد ·(910) · اساسيات في تدريس الاجتماعيات وتطبيقاتها

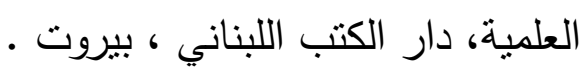

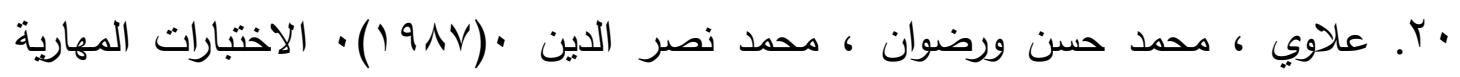
والنفسية في المجال الرياضي ، طا ، ، دار الفكر العربي • 


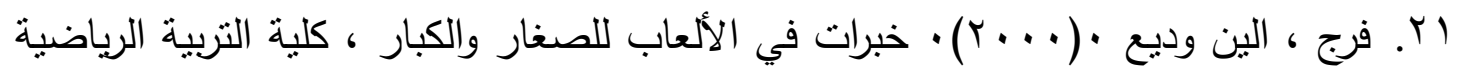

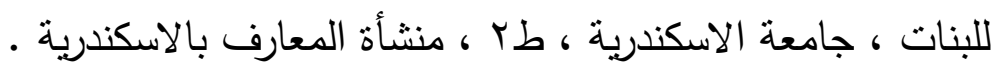

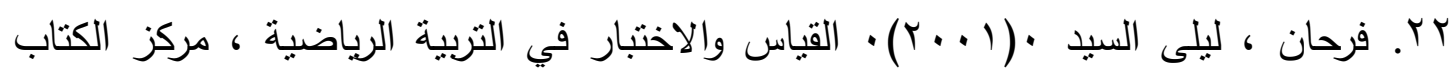

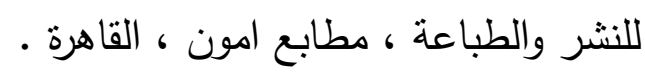

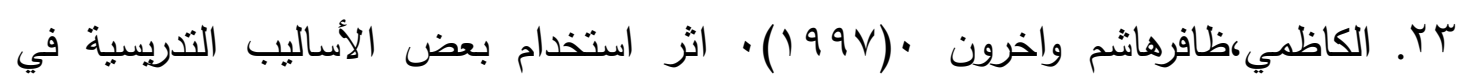

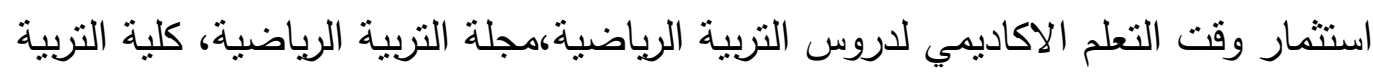
الرياضية ، جامعة بغداد ، العدد (r).

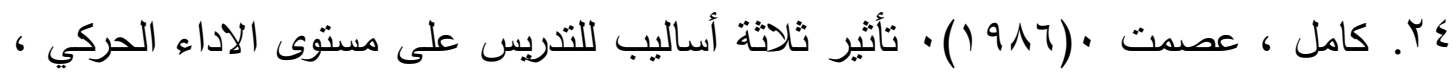

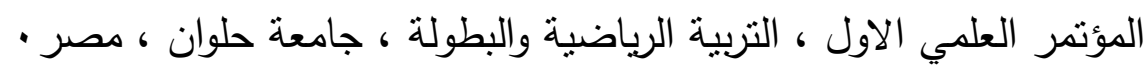

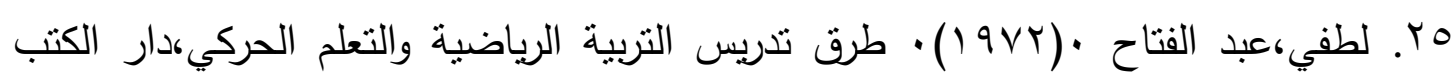

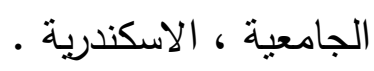

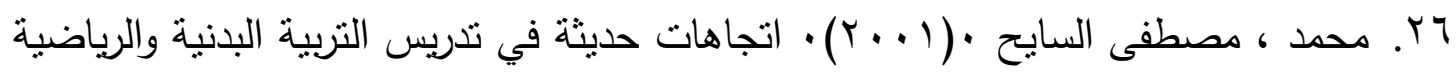

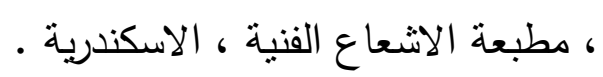

rV

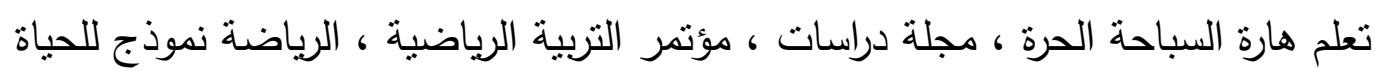

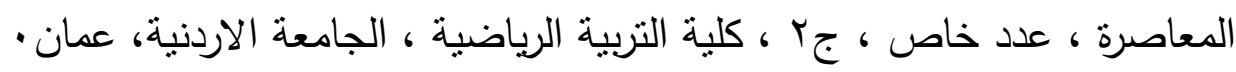

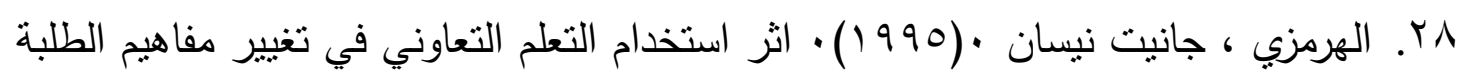

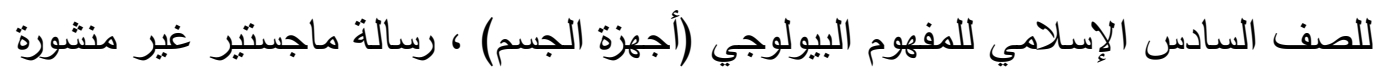
، الجامعة الأردنية ، كلية الدراسات العليا.

29. Chalip, I. Csikszent Mihalyi, M. Kleiber, D. Larson, R. (1984). Variations of experience in formal sport, Resaerch Quarterly,55. U.S.A

30. Mosston, M \& Ashowarth, S. (1994). Instructional design in physical education class, 5. U.S.A

31. Mosston, M. \& Ashworth A. (2001). Teaching Physical Education, Forth Edition, New York, micmillan College Publishing. U.S.A

32. Slavin, R. (1980). Cooperative learning, Review of Educational Research, Vol.50. No. (2). U.S.A

33. Watson, B. (1995). Cooperative Learning in Teacher Education, J. of teacher Education, Vol. 46. No. 4. U.S.A 
الملحق (1) السادة الخبراء والمتخصصين

\begin{tabular}{|c|c|c|c|c|c|c|c|}
\hline التعليمية & الثخصية & الالبتلية & 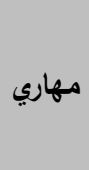 & بذني & 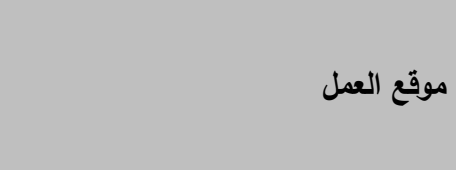 & اسم الخبير & $ت$ \\
\hline & $x$ & & & $x$ & كلية التربية الرياضية / جامعة الموصل & أ.د. وديع ياسين التكريتي & 1 \\
\hline \multirow[t]{5}{*}{$x$} & & & $x$ & $x$ & كلية التربية الرياضية / جامعة بذاد & أ.د. عبد الله المشهداني & $r$ \\
\hline & & & & $x$ & كلية التربية الرياضية / جامعة الموصل & أ.د. ياسين طه محمد علي & $r$ \\
\hline & & & & & كلية التربية / جامعة الموصل & أ.د. يوسف حنا للو & $\varepsilon$ \\
\hline & & & $x$ & $x$ & كلية التربية الرياضية / جامعة الموصل & أ.د. عامر محمد سعودي & 0 \\
\hline & & & $x$ & $x$ & كلية التربية الرياضية / جامعة الموصل & أ.د. جاسم محمد نايف & 7 \\
\hline \multirow[t]{2}{*}{$x$} & & & $x$ & $x$ & كلية التربية الرياضية / جامعة الموصل & أ.د. قتيبة زكي التك & 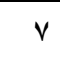 \\
\hline & & & & $x$ & كلية التربية الرياضية / جامعة الموصل & أ.د. محمد خضر أسمر & $\wedge$ \\
\hline \multirow[t]{3}{*}{$x$} & & & $x$ & $x$ & كلية التربية الرياضية / جامعة بذاد & أ.م.د. فاطمة ناصر حسين & 9 \\
\hline & & & $x$ & $x$ & كلية التربية / جامعة الموصل & أ.م.د. عبد الرزاق ياسين & 1. \\
\hline & & & $x$ & $x$ & كلية التربية الرياضية / جامعة بذاد & أ.م.د. محمد صالح & 11 \\
\hline \multirow[t]{8}{*}{$\times$} & & & $x$ & $x$ & كلية التربية الرياضية / جامعة الموصل & أ.م.د. حازم مطرود & ir \\
\hline & & & & $x$ & كلية التربية الرياضية / جامعة الموصل & أ.م.د. عناد جرجيس & ir \\
\hline & $x$ & $x$ & $x$ & $x$ & كلية التربية الرياضية / جامعة الموصل & أ.م.د. هاثم أحمد سليمان & $1 \leqslant$ \\
\hline & & & $x$ & $x$ & كلية التربية الرياضية / جامعة الموصل & أ.م.د. عبد الكريم قاسم & 10 \\
\hline & & & & $x$ & كلية التربية الرياضية / جامعة الموصل & أ.م.د. اياد محمد عبد الله & 17 \\
\hline & & $x$ & & $x$ & كلية التربية الرياضية / جامعة الموصل & أ.م.د. ثيلام يونس علاوي & iv \\
\hline & & $x$ & & & كلية التربية الرياضية / جامعة الموصل & أ.م.د. خالد فيصل الثيخو & 11 \\
\hline & & $x$ & $x$ & $x$ & كلية التربية الرياضية / جامعة البصرة & أ.م.د. احمد عبد العزيز & 19 \\
\hline \multirow[t]{3}{*}{$x$} & & & $x$ & $x$ & كلية التربية الرياضية / جامعة الموصل & أ.م.د. طلال نجم عبد الله & $r$. \\
\hline & & $x$ & & & كلية التربية الرياضية / جامعة الموصل & أ.م.د.ناظم شاكر الوتار & r \\
\hline & & & & & كلية التربية / جامعة الموصل & أ.م.د. ايناس يونس & rr \\
\hline \multirow[t]{3}{*}{$x$} & & & $x$ & $x$ & كلية التربية الرياضية / جامعة الموصل & أ.م.د. افراح ذنون يونس & rr \\
\hline & & $x$ & $x$ & $x$ & كلية التربية الاساسية / جامعة الموصل & أ.م.د. سعد فاضل & $r \leqslant$ \\
\hline & & $x$ & $x$ & $x$ & كلية التربية الرياضية / جامعة الموصل & أ.م.د. رياض أحمد & ro \\
\hline \multirow[t]{2}{*}{$x$} & & & $x$ & $x$ & كلية التربية الرياضية / جامعة الموصل & أ.م. .د.ليث محمد داؤد & rq \\
\hline & $x$ & $x$ & $x$ & $x$ & كلية التربية الرياضية / جامعة الموصل & م.د. أياد محمد شيت & rv \\
\hline$x$ & & & $x$ & $x$ & كلية التربية الرياضية / جامعة الموصل & أ.م •د صفاء ذنون الامام & rA \\
\hline \multirow[t]{2}{*}{$x$} & & & $x$ & $x$ & كلية التربية الرياضية / جامعة الموصل & م.د.زهيريحينالمعاضيدي & rq \\
\hline & $x$ & $x$ & $x$ & $x$ & كلية التربية الرياضية / جامعة الموصل & م.خالا محمود عزيز & $r$. \\
\hline
\end{tabular}

